๑ Entomologica Fennica. 9 December 2002

\title{
An annotated checklist of geometrid moths (Lepidoptera: Geometridae) from the Kamchatka Peninsula and adjacent islands
}

\author{
Evgeny A. Beljaev \& Sergei V. Vasilenko
}

Beljaev, E. A. \& Vasilenko, S. V. 2002: An annotated checklist of geometrid moths (Lepidoptera: Geometridae) from the Kamchatka Peninsula and adjacent islands. - Entomol. Fennica 13: 195-235.

A checklist of the Geometridae of the Kamchatka Peninsula and the adjacent islands is presented. A total of 80 species are recorded, and 20 species are omitted as doubtful for the fauna of the territory. One new species and five new subspecies are described (Xanthorhoe okhotinaria Beljaev \& Vasilenko sp. n., Xanthorhoe okhotinaria sikhotenaria Beljaev \& Vasilenko ssp. n., Dysstroma citratum kamtshadalarium Beljaev \& Vasilenko ssp. n., Hydriomena impluviata djakonovi Beljaev ssp. n., Epirrita autumnata smetanini Beljaev ssp. n., Eupithecia kurilensis mironovi Beljaev ssp. n.). One species is recorded as new for the Russian Far East (Kamchatka Peninsula included) (Macaria halituaria [Guenée, 1858]). Two species are recorded as new for the Kamchatka Peninsula: Eupithecia antaggregata Inoue, 1977 and Eupithecia gelidata Möschler, 1860, and three species are recorded as new for the North Kuril Islands (Xanthorhoe derzhavini [Djakonov, 1931], Entephria caesiata [Denis \& Schiffermüller, 1775] and Psychophora sabini [Kirby, 1824]). In addition, several species are reported for the first time in neighbouring territories: two species for Magadan Province (Xanthorhoe ferrugata [Clerck, 1759] and Xanthorhoe kamtshatica [Djakonov, 1929]); four species for North Koryakiya (Entephria caesiata [Denis \& Schiffermüller, 1775], Eulithis populata [Linnaeus, 1758], Eupithecia gelidata Möschler, 1860, Carsia sororiata [Hübner, 1813]) and three species for Chukotka (Xanthorhoe kamtshatica [Djakonov, 1929], Xanthorhoe derzhavini [Djakonov, 1931] and Rheumaptera hastata [Linnaeus, 1758]).

Evgeny A. Beljaev, Institute of Biology and Soil Science, Far Eastern Branch of Russian Academy of Sciences, Stoletia Street, 159, Vladivostok-22, 690022, Russia;E-mail: beljaev@ibss.dvo.ru

Sergei V. Vasilenko, Institute of Systematic and Ecology of Animals, Siberian Branch of Russian Academy of Sciences, Frunze Street, 11, Novosibilsk-91, 630091,Russia;E-mail:mu@eco.nsc.ru

Received 21 November 2001, accepted 14 August 2002 


\section{Introduction}

The geometrid fauna of the Kamchatka Peninsula has received more attention than any other territory in the Far East north of the Amur basin. The studies have a history of over 100 years. Initially, Alpheraky (1897) reported a brief list of Geometridae, based on a small collection made by Dr. O. Herz during his trip to the Kamchatka in 1890. About 40 years later, Djakonov $(1929,1931)$ published two full reviews of Kamchatian Geometridae based on collections obtained during the Swedish expeditions to Kamchatka, carried out in 1920-1922, and on material kept in the Zoological Institute, St Petersburg. A. Kurentzov and his colleagues carried out a comprehensive investigation of the Kamchatian entomofauna in 19581960. Abundant material was collected during this expedition but, unfortunately, most of it has not been studied. Only a few species of geometrid moths were mentioned in the publications of results of the expedition (Kurentzov 1963, 1966). More recently Sedykh (1979) compiled a list of the Macrolepidoptera of Kamchatka, based on published data and on his own numerous specimens obtained from the Peninsula. However, regarding the Geometridae, the list contains a number of doubtful identifications of species and misprints. From the islands adjacent to the Kamchatka Peninsula, closely connected with the Peninsula historically, a small number of Geometridae species have been reported from the North Kuril Islands (Bryk 1942, Konovalova 1970), and only one species from the Komandor Islands (Viidalepp 1996). Data on the biology of the Geometridae of the Kamchatka Peninsula are very incomplete. Only a few species have been studied for this purpose (Kurentzov \& Ivliev 1960, Ivliev 1963, 1966, Ivliev \& Kononov 1962, Lobkova 1986, Beljaev 1988, 1995, Smetanin 1990).

Thus, the most important publications on the Kamchatian Geometridae are very old, and data from recent works needs to be reviewed and consolidated. The present publication represents results of revision of the published data and original investigation of new material of geometrid moths from the Kamchatka Peninsula and adjacent islands (Verkhoturov, Karaginskii, Bering, Shumshu, Paramushir).

\section{Material and methods}

This investigation was mainly based on the examination of the abundant material kept at the Institute of Biology and Soil Science (Vladivostok). This material has been obtained mostly during the entomological expeditions of the Far Eastern Branch of the Siberian Department of Academy of Sciences of the USSR to the Kamchatka Peninsula (19581960) and to the North Kuril Islands (1964), headed by Prof. A. Kurentzov (collectors A. Kurentzov, N. Azarova, L. Ivliev, D. Kononov, Z. Konovalova, G. Krivolutzkaja, A. Kupyansklaya, V. Minchenko and S. Safronova), and on the specimens collected during the joint Japanese-Russian expedition to the Kamchatka Peninsula and North Kuril Islands (1996-1997, collectors E. Makarchenko, S. Kholin, R. B. Kuranishi and Yu. Tshistjakov), of which a brief review of the results has been published recently (Beljaev \& Kuranishi 2000). Additionally, material was examined from the Insect collection of the IBSS (Russian Academy of Sciences, Vladivostok), from Karaginskii Island in 1929 (collected by Mr. V. Razumovskii), south of Kamchatka Peninsula mainly in 1976 and in 1977 (collected by Dr. V. Kirpichnikova, Gorno-Tayezhnaya Station of Russian Academy of Sciences, Ussuriisk), central Kamchatka in 1991 (collected by Dr. A. Martyinenko, Far Eastern State University, Vladivostok), North Kuriles in 1996 and in 1997 (collected by Prof. A. Lelei, IBSS). A small number of specimens of Kamchatian Geometridae collected by Mr. O. Kosterin (Kamchatka Peninsula in 1991 and in 1992, and Magadan District in 1989), Mr. O. Kazantsev (Middle Kavycha River in 1968) and Mr. I. Lyubechanskii (North Koryakiya in 1991) which are kept in the Institute of Systematic and Ecology of Animals (Novosibirsk), as well as specimens received from amateur entomologist Mr. A. Smetanin (Petropavlovsk-Kamchatskii) (collected from Kichiga River and Verkhoturov Island mainly in 1986 and in 1995) and from the research officer of the Kronotzkii Reserve, Mrs. L. Lobkova (Petropavlovsk-Kamchatskii) were also used in the study. In addition, all available published data have been taken into account.

The synonymy, material examined, distribution and biology of the geometrid moths from the investigated territory are summarised in the checklist. In the synonymy following the current scientific name, the names described and referred to the Kamchatka Peninsula and adjacent islands, based on the original material, and those cited from the region in the most important faunal revisions (Staudinger \& Rebel 1901, Prout 1912-1916, Whirl 1939-1953, Viidalepp 1975, 1976, 1977, 1978, 1996), are included. Numerous names of aberrations, mentioned in the literature for the Kamchatian Geometridae, are not cited in the synonymy as unavailable names according to the International Code of Zoological Nomenclature, 1999 (Article 45.6.2.). The nomenclature follows Parsons et al. (1999), with some necessary additions, changes and comments. Summarised data from the reviewed literature are given under headings "Localities" or "Additional localities", other data are listed in "Material examined". The localities are arranged following 
the sequence on the map of collecting sites (Fig. 1).

Distributions of the species are summarised from the most recent faunal compilations (Inoue 1982, Covell 1983, Ferguson 1983, Mironov 1990, 1991, Viidalepp 1996, Müller 1996, Lafontaine \& Wood 1997), other publications covering original material from the investigated territory, data of the entomological collections of the Institute of $\mathrm{Bi}$ ology and Soil Science (Vladivostok) and the Institute of Systematic and Ecology of Animals (Novosibirsk). Emphasis is given to the distribution of subspecies occurring in the Kamchatka Peninsula.

It should be noted that this paper covers the Kamchatka Peninsula but not Kamchatka per se in the sense of the Kamchatsk Province (including Koryakiya), which includes also continental territories adjacent to the Peninsula in the north (North Koryakiya in the text). However, some specimens from adjacent territories are cited in the chapter "Material examined" where appropriate. After the proper checklist, a list of doubtful records for the Kamchatka Peninsula and adjacent islands is given.

Abbreviations of museums:

IBSS — Institute of Biology and Soil Science, Vladivostok NHR — Naturhistoriska Riksmuseet, Stockholm SZMN — Siberian Zoological Museum, Novosibirsk

\section{An annotated checklist of Geometridae of the Kamchatka Peninsula and adja- cent islands}

\section{Family Geometridae}

\section{Subfamily Archiearinae}

\section{Archiearis parthenias sajana (Prout, 1912)}

Brephos parthenias (Linnaeus, 1761) var.: Alpheraky 1897: 339; Prout 1912.

Brephos parthenias: Sedykh 1979: 292.

Material examined. 1 male, Elisovo, 20.IV.1985

L. Lobkova leg.

Additional localities. Zhupanovo.

Distribution. Subspecies sajana: Far East (Kamchatka Peninsula, Amursk Province, south of Khabarovsk Territory, Primorsk Territory), Yakutia, South Siberia mountains), North Mongolia. The other subspecies: Europe, West Siberia, Sakhalin Island, Japan.

Remarks. The examined specimen is similar to the moths from the Amur basin in wing shape and in having larger white spots on the forewing, but the specimen here is somewhat smaller. It

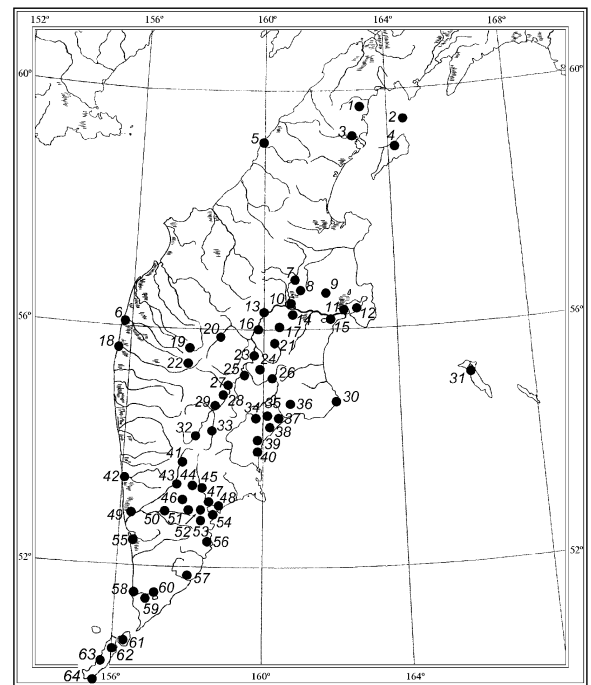

Fig. 1. Collecting sites in the Kamchatka Peninsula and on adjacent islands. 1 - Kichiga River; 2 Verkhoturova Island; 3 - Karaga River; 4 Karaginskii Island; 5 - Palana; 6 - Ust'-Sopochnoe; 7 - Elovka River; 8 - Shiveluch volcano; 9 Upper Raduga River; 10 - Zarechnyi range; 11 Ust'-Kamchatsk; 12 - Nerpich'e Lake; 13 - Ushki; 14 - Klyuchi; 15 - Azhabach'e Lake; 16 Kosyrevsk; 17 - Klyuchevskaya Sopka volcano; 18 - Ichinskii; 19 - Aga Mt.; 20 - Esso; 21 - Tolbachik Mt.; 22 - Kopyl'e River 23 - Laso; 24 - Nikolka Mt.; 25 - Shchapino; 26 - Upper Shchapina River; 27 - Mashura; 28 - Kirganik River; 29 - Mil'kovo; 30 - Kronotskii Cape; 31 - Beringa Island 32 Pushchino; 33 - Middle Kavycha River; 34 - Uson volcano; 35 - Shumnaya River; 36 - Bogachevka River; 37 - Kikhpinych volcano; 38 - Geisernaya River and "Gornoe Plato" tourist centre; 39 Barmotina River; 40 - Zhupanovo; 41 - Gannaly; 42 - Kikhchik; 43 - Malki; 44 - Koryaki; 45 Razdol'nyi; 46 - Nachiki (Nachiki, Nachikinskoe Lake, Nachikinskoe Zerkal'tse Mt.); 47 - Elisovo and Pogranichnyi; 48 - Pertopavlovsk-Kamchatskii; 49 - Ust'-Bol'sheretsk; 50 - Apacha; 51 Vachkazhech volcano; 52 - Sosnovka; 53 Paratunka; 54 - Tarja (Vilyuchinsk); 55 Bol'sheretsk; 56 - Akhomten Bay (Russkaya Bay); 57 - Topkaya River; 58 - Ozernovskii; 59 Pauzhetka; 60 - Kuril'skoe Lake; 61 - Shumshu Island (Kosyrevskoe, Bol'shoe Lake, Pochtareva Cape and Yaugich Cape); 62 - Severo-Kuril'sk and Ebecko volcano; 63 - Shelekhov Bay, Ban'chzhou and Shelekhovka River; 64 - Vasilyeva Peninsula.

conforms well to the description by Alpheraky (1897) of an unnamed Kamchatian variety. 
Leucobrephos middendorffi ussuriensis (Moltrecht, 1909)

Leucobrephos middendorffi middendorffi (Ménétriès, 1858): Viidalepp 1996: 11 [misidentification]

Material examined. 1 male, Upper Shchapina River, 22.VI.1984 A. Smetanin leg.

Distribution. Subspecies ussuriensis: Far East (Kamchatka Peninsula, south of Khabarovsk Territory, mountains of Primorsk Territory). The other subspecies: Mountains of South Siberia, central Yakutia.

Biology. The single specimen was collected in Betula ermanii forest.

Remarks. The specimen is similar to Leucobrephos middendorffi ussuriensis from the Amur basin in having a white postmedial transverse line on the forewing diffuse and with distal projection narrow and sharply angled, and, on the hindwing, in having a narrow black basal area and wide black external margin. It differs from the latter in having the white transverse lines on the forewing wider and somewhat indistinct. Reference of the nominotypical subspecies of Leucobrephos middendorffi from the Amur basin and the Kamchatka Peninsula (Viidalepp 1996) is doubtful.

\section{Subfamily Ennominae}

Lomaspilis marginata amurensis (Hedemann, 1881)

Abraxas marginata (Linnaeus, 1758): Alpheraky 1897: 341; Staudinger \& Rebel 1901: 324.

Lomaspilis marginata opis (Butler, 1878): Djakonov

1929: 19; Djakonov 1931: 408 [misidentification]

Lomaspilis marginata: Sedykh 1979: 293; Beljaev \&

Kuranishi 2000: 235.

Lomaspilis opis: Sedykh 1979: 293.

Lomaspilis marginata amurensis: Viidalepp 1996: 65.

Material examined. 27 males, 2 females: Azhabach'e Lake (Bushuika River), $15 \mathrm{~km} \mathrm{NE}$ of Esso (Pravaya Kamchatka River), Shchapino, 17 km NE of Malki (Poperechnaya River), "Middle Avacha River" (Razdol'nyi), Nachiki, Elisovo, Paratunka, Pauzhetka, from 18.VI. to 28.VII.

Additional localities. Klyuchi, Pogranichnyi, Petropavlovsk-Kamchatskii.
Distribution. Subspecies amurensis: Far East (Kamchatka Peninsula, Amursk Province, south of Khabarovsk Territory, Primorsk Territory, Sakhalin Island, South Kuril Islands), China, Korea, Japan (Hokkaido). The other subspecies: Europe, Urals, West and Central Siberia, Transbaikalia, Kazakhstan, Middle Asia (Tian-Shan' Mts), North Mongolia.

Biology. In the Kamchatka Peninsula the species prefers lowland river valleys with Salix and Populus forests.

Remarks. The examined specimens are superficially similar to ones from the Amur basin but somewhat smaller, and they vary strongly in their wing markings from typical to almost white. In the male genitalia the valvae, uncus, gnathos and cornuti are almost the same as in Amurian specimens but the aedeagus is markedly smaller. Tentatively, Kamchatian Lomaspilis marginata can be associated with the subspecies Lomaspilis marginata amurensis.

\section{Chiasmia clathrata clathrata (Linnaeus, 1758)}

Phasiane clathrata: Alpheraky 1897: 342; Staudinger \& Rebel 1901: 353.

Chiasma [misspelling] clathrata: Djakonov 1929: 20, 21, 23; Djakonov 1931: 410; Sedykh, 1979: 293;

Chiasma [misspelling] clathrata: Beljaev \& Kuranishi 2000: 235.

Semiothisa (Chiasmia) clathrata: Wehrli 1940: 389.

Material examined. 13 males, 9 females: Klyuchi, Azhabach'e Lake (Bushuika River), $15 \mathrm{~km}$ NE of Esso (Pravaya Kamchatka River), "Sovhoz Tsentral'nyi" (10 km N of Laso), Shchapino, $17 \mathrm{~km}$ NE of Malki (Poperechnaya River), Pauzhetka, from 2.VII. to 28.VII.

Additional localities. Kosyrevsk, Elisovo, Pogranichnyi, Petropavlovsk-Kamchatskii.

Distribution. Nominotypical subspecies: Europe, Asia Minor, Caucasus, Transcaucasia, Siberia (except extreme north), north of the Far East (Magadansk Province, Kamchatka Peninsula). The other subspecies: North Africa, North Iran, Kazakhstan, east of Middle Asia, south of the Far East (Amursk Province, south of Khabarovsk Territory, Primorsk Territory, Sakhalin Island, South Kuril Islands), China, Korea, Japan.

Biology. The species widely inhabits forests 
and meadows in lowlands and submontane zones.

Remarks. Kamchatian specimens are similar to the nominotypical subspecies in wing marking, but not to the subspecies Chiasmia clathrata djakonovi Kardakoff, 1928, from the Amur basin, or to the subspecies from the Kuril Islands and Japan.

\section{Macaria signaria (Hübner, 1809)}

Macaria signaria: Djakonov 1929: 19; Djakonov 1931: 409. Semiothisa signaria: Viidalepp 1978: 759; Sedykh 1979: 293; Viidalepp 1996: 74.

Localities. Kosyrevsk.

Distribution. Europe, Turkey, Caucasus, Transcaucasia, Urals, Siberia (except north), Far East (Kamchatka Peninsula, Amursk Province, south of Khabarovsk Territory, mountains of Primorsk Territory, Sakhalin Island), North Iran, Japan, North America (Yukon to Newfoundland, south to North Carolina, New Mexico, Arizona and California).

Remarks. Only a single specimen is known from the Kamchatka Peninsula, collected in LarixBetula forest during the Swedish Kamchatian Expedition 1920-1922 (Djakonov 1929).

\section{Macaria brunneata brunneata (Thunberg, 1784)}

Itame fulvaria (Villers, 1789): Djakonov 1929: 20, 23; Djakonov 1931: 410; Wehrli 1940: 398; Kurentzov 1963: 25, 27, 43, 51; Kurentzov 1966: 69; Sedykh 1979: 293.

Itame brunneata: Viidalepp 1978: 760; Beljaev \& Kuranishi 2000: 236 .

Itame brunneata brunneata: Viidalepp 1996: 76.

Material examined. 20 males, 27 females: Elovka River ("Lespromkhoz"), $10 \mathrm{~km} \mathrm{~N}$ of Gannaly, Nachiki, Nachiki (Bezymyannoe Lake), Maloe Nachikinskoe Lake, from 25.VII. to 16.VIII.

Additional localities. Esso, Nikolka Mt., Mashura, Mil'kovo, Uson volcano, Shumnaya River, Elisovo. Kurentzov (1963) noted this species from south-west of the Kamchatka Peninsula (Ust'-Bol'sheretskii District) without specific locality.

Distribution. Nominotypical subspecies: Europe (except south), Siberia, Far East (Magadansk
Province, Kamchatka Peninsula, Amursk Province, Khabarovsk Territory), Mongolia. The other subspecies: South of the Far East (Primorsk Territory, Sakhalin Island), Korea (North), Japan (Honshu, mountains), North America (Alaska to Newfoundland south to New England, Michigan and Wyoming).

Biology. In the Kamchatka Peninsula the species prefers tundra and crowberry brakes in the lowland, and alpine meadows and tundra in the mountains.

Remarks. On their facies the examined specimens are similar to ones from the nominotypical subspecies.

\section{Macaria loricaria (Eversmann, 1837)}

Itame loricaria: Djakonov 1929: 2; Djakonov 1931: 410; Sedykh 1979: 293; Beljaev \& Kuranishi 2000: 236.

Material examined. 1 male, Nachiki, 16.VII.1996

Yu. Tshistjakov leg.

Additional localities. Esso, Shchapino, Mil'kovo, Elisovo.

Distribution. North and Northeast Europe, Urals, Siberia (Transbaikalia, Central Yakutia), Far East (Magadansk Province, Kamchatka Peninsula, north of Amursk Province, Sakhalin Island), North Mongolia, North America (Alaska to Newfoundland, south to New York and Colorado).

\section{Macaria halituaria (Guenée, 1858) comb. n.}

Itame wauaria (Linnaeus, 1758): Djakonov, 1929: 20; Djakonov 1931: 410; Sedykh 1979: 293; Viidalepp 1996: 75 [misidentification]

Itame wanaria [misspelling]: Semakov 1972: 61.

Abraxas grossulariata (Linnaeus, 1758): Semakov 1971: 281 [misidentification?]

Material examined. 13 males, 20 females, SW slope of Shiveluch volcano (Baidarka River), 17. VIII. 1958 A. Kurentzov, L. Ivliev \& D. Kononov leg.; 2 females, "Sovhoz Tsentral'nyi" (10 km N of Laso), 7.VIII.1958 A. Kurentzov, L. Ivliev \& D. Kononov leg.; 1 male, Mil'kovo, 31.VII.1976

A. Kupyanskaya leg.

Additional localities. Esso, Shchapino, Pogranichnyi. 
Distribution. South and East Siberia (Altai and Sayan Mts, Tuva, Buryatia, Transbaikalia, Yakutia), Far East - first record (Magadansk Province, Kamchatka Peninsula, Amursk Province, Khabarovsk Territory, Sakhalin Island, East Kazakhstan, mountains of Middle Asia, Northwest China, Mongolia.

Biology. In the Kamchatka Peninsula the species is apparently local and inhabits lowland and low montane forests preferring those with Populus and Alnus. Its larvae are noted as pests of black and red currant (Semakov 1972).

Remarks. The "Itame wauaria", recorded from the East Siberia and Far East by different authors, is a misidentification in part of Macaria halituaria and in part of Macaria sp. (probably chinensis Sterneck, 1928). Special review of the Macaria wauaria species group in Siberia and Far East will be published separately. The examined Kamchatian specimens clearly belong to Macaria halituaria. Abraxas grossulariata was noted by Semakov (1971) as a pest of various berry cultures in the Kamchatka Peninsula. Possibly, it is misidentification of Macaria halituaria because later this author referred to the same case as "Itame wauaria" (Semakov 1972). In Parsons et al. (1999), Halia halituaria (Guenée, 1858) is included in the genus Isturgia Hübner, [1823], evidently erroneously, because close relationship of this species with Macaria wauaria is evident from the original description of the discussed taxon.

\section{Pygmaena fusca (Thunberg, 1792)}

Pygmaena fusca: Viidalepp 1978: 760; Viidalepp 1996: 75.

Material examined. 2 males, Kichiga River, 15.VII.1987 A. Smetanin leg. North Koryakiya: 7 males, 1 female, Dezhneva Bay, 12, 25.VII.1991 I. Lyubechanskii leg.

Distribution. North and Central Europe (mountains), Polar Urals, North Yakutia, north of the Far East (North Koryakiya, north of the Kamchatka Peninsula).

Biology. In the Kamchatka Peninsula the species was collected in a maritime upland meadow.

Remarks. The Kamchatian specimens are similar to the North European ones.

\section{Selenia dentaria (Fabricius, 1775)}

Selenia bilunaria (Esper, 1795): Alpheraky 1897: 341; Staudinger \& Rebel 1901: 327; Djakonov 1929: 19; Djakonov 1931: 409; Sedykh 1979: 293.

Selenia bilunaria minima Strand 1901: Wehrli 1940: 326. Selenia bilunaria alpestris Wehrli 1940: Viidalepp 1979a: 794;

Selenia dentaria alpestris: Viidalepp 1996: 68.

Selenia dentaria: Beljaev \& Kuranishi 2000: 236.

Material examined. 7 males: Azhabach'e Lake (Bushuika River), $15 \mathrm{~km}$ NE of Esso (Pravaya Kamchatka River), 30 km SE of Ichinskaya Sopka volcano (Kopyl'e River), 17 km NE of Malki (Poperechnaya River), Elisovo, from 6.VII. to 13.VII.

Additional localities. Kluychi, Zhupanovo, Pogranichnyi, Petropavlovsk-Kamchatskii.

Distribution. Northeast Europe, North Siberia (south to Buryatia), Far East (Kamchatka Peninsula, Amursk Province, south of Khabarovsk Territory, mountains of Primorsk Territory), Mongolia, Europe, Caucasus, Transcaucasia.

Biology. In the Kamchatka Peninsula the species is found occasionally, in various types of forests in the lowlands and in the mountains up to $1000 \mathrm{~m}$ above sea level.

Remarks. Wehrli (1940) notes the similarity of the Northeast Siberian and Kamchatian specimens of the species with subspecies Selenia dentaria minima, described from North Norway. Viidalepp (1979a, 1996) used the name alpestris (proposed originally for the Alpine population, resembling subspecies minima Strand) for populations of Selenia dentaria from North Europe to Kamchatka and Amur basin. The distributional range and validity of the subspecies minima needs to be studied.

\section{Lycia hirtaria (Clerck, 1759)}

Lycia hirtraria: Sedykh 1979: 293.

Localities. Elisovo, Pogranichnyi.

Distribution. Europe (except South-East),

Caucasus, Transcaucasia, Asia Minor, east of Middle Asia, South Siberia, Central Yakutia, Far East (Kamchatka Peninsula, Amursk Province, south of Khabarovsk Territory, Primorsk Terri- 
tory, Sakhalin Island), Japan (Hokkaido).

Remarks. Only two specimens are known from the Kamchatka Peninsula.

\section{Lycia pomonaria (Hübner, 1790)}

Poecilopsis pomonaria: Sedykh 1979: 293.

Localities. Pogranichnyi. Distribution. North and Central Europe, North Kazakhstan, South Siberia, Far East (Kamchatka Peninsula, Khabarovsk Territory, mountains of Primorsk Territory).

Remarks. A single specimen is known from the Kamchatka Peninsula.

\section{Alcis extinctaria (Eversmann, 1851)}

Boarmia extinctaria: Alpheraky 1897: 341; Staudinger \& Rebel 1901: 341; Djakonov 1929: 19; Djakonov 1929: 23; Djakonov 1931: 409; Wehrli 1943: 505; Sedykh 1979: 293.

Alcis extinctaria: Viidalepp 1996: 87; Beljaev \& Kuranishi 2000: 236.

Material examined. 26 males, 27 females: Klyuchi, "Borovoe" (20 km N of Laso), "Sovhoz Tsentral'nyi" (10 km N of Laso), Laso, Shchapino, Mil'kovo, $17 \mathrm{~km}$ NE of Malki (Poperechnaya River), "Khutor, MTS" (Razdol'nyi), Petropavlovsk-Kamchatskii, Shumshu Island, from 7.VII. to 5.IX.

Additional localities. Aga Mt., Tolbachik Mt., Pushchino, Nacihki, Elisovo, Pogranichnyi, Sosnovka.

Distribution. Nominotypical subspecies: Far East (Kamchatka Peninsula, Amursk Province, Khabarovsk Territory, mountains of Primorsk Territory, north of Sakhalin Island, North Kuril Islands), East Siberia (south of Evenkiya, Altai, Sayan Mts, Tuva, North Baikal region, Transbaikalia), Mongolia. The other subspecies: South of Sakhalin Island, Korea, Japan.

Biology. In the Kamchatka Peninsula the species is common in Betula and Larix forests in the lowlands and submontane zones.

Remarks. The examined specimens from the Kamchatka Peninsula are similar to those from South Siberia and especially from the central
Khabarovsk Territory, but on average they are somewhat smaller and paler coloured, and some of them have whitish ground colour on the wings (aberration clarior Djakonov, 1929, infrasubspecific name).

\section{Ematurga atomaria krassnojarscensis Fuchs, 1899}

Ematurga atomaria (Linnaeus, 1758): Alpheraky 1897:341; Djakonov 1929: 20; Djakonov 1931: 409; Kurentzov 1963: 37; Sedykh 1979: 293; Beljaev \& Kuranishi 2000: 236.

Ematurga atomaria minuta Heydemann 1925: Djakonov 1931: 409; Sedykh 1979: 293.

Ematurga atomaria krassnojarscensis: Wehrli 1953: 647; Viidalepp 1979a: 788; Viidalepp 1996: 85.

Material examined. 78 males, 26 females: Azhabach'e Lake (Bushuika River), Laso, Shchapino, Upper Geisernaya River, Zhupanovo, Mil'kovo, $40 \mathrm{~km}$ NE of Mil'kivo (Kirganik River, "Bichki"), $17 \mathrm{~km}$ NE of Malki (Poperechnaya River), "Middle Avacha River, Khutor, MTS" [Razdol'nyi], Paratunka, from 12.V. to 20.VII.

Additional localities. Klutchi, Tolbachik Mt., Elisovo, Pogranichnyi.

Distribution. Subspecies krassnojarscensis: Central and East Siberia, Far East (Kamchatka Peninsula, Amursk Province, Khabarovsk Territory, mountains of Primorsk Territory, Sakhalin Island), North Mongolia. The other subspecies: Europe, Asia Minor, Caucasus, Transcaucasia, West Siberia, Kazakhstan, Middle Asia, China (Tibet).

Biology. The species is one of the commonest geometrid moths in the Kamchatka Peninsula. It flies in Larix and Betula forests, and in lowland tundra.

Remarks. Wehrli (1953) asserts that specimens of this species from the Kamchatka Peninsula conform well to the description of the subspecies Ematurga atomaria krassnojarscensis. However, he notes that a number of specimens from South Siberia and the Amur basin are not clearly distinguished from the Laplandian subspecies Ematurga atomaria obsoletaria (Zetterstedt, 1840), currently treated as a synonym of the nominotypical subspecies. Besides that, he cites the opinion of Djakonov (1929) about the similarity of the Kamchatian Ematurga atomaria with specimens 
from Leningrad, which were referred to subspecies obsoletaria. So, the taxonomy of Kamchatian Ematurga atomaria needs to be revised. It should be noted that specimens from the Kamchatka Peninsula are more similar to those from the Amur basin than to those from Yakutia.

\section{Cabera exanthemata exanthemata (Scopoli, 1763)}

Cabera exanthemata: Alpheraky 1897: 341; Djakonov 1929: 19, 23; Djakonov 1931: 409; Sedykh 1979: 293; Viidalepp 1996: 66; Beljaev \& Kuranishi 2000: 236.

Material examined. 88 males, 7 females: Azhabach'e Lake (Bushuika River), $15 \mathrm{~km} \mathrm{NE}$ of Esso (Pravaya Kamchatka River), Shchapino, Mil'kovo, Middle Kavycha River, Zhupanovo, 17 km NE of Malki (Poperechnaya River), Nacihki (Nachikinskoe Zerkal'tse Mt.), Paratunka, Pauzhetka, from 20.VI. to 27.VII.

Additional localities. Klyuchi, Ust'Sopochnoe, Ichinskii, Shumnaya River, Elisovo, Pogranichnyi, Petropavlovsk-Kamchatskii.

Distribution. Nominotypical subspecies: Europe, Caucasus, Transcaucasia, Kazakhstan, Middle Asia (mountains), Siberia (except extreme north), north of the Far East (Magadansk Province, Kamchatka Peninsula, north of Amursk Province, north of Khabarovsk Territory), Mongolia. The other subspecies: South of the Far East (south of Amursk Province, south of Khabarovsk Territory, Primorsk Territory, Sakhalin Island, South Kuril Islands), Korea, Japan, North America (Alaska to central Manitoba, south to Alberta and British Columbia).

Biology. The species is the one of the commonest geometrids in the Kamchatka Peninsula in lowland river valleys with Salix and Populus forests, but it occurs in Larix and Betula forests too.

Remarks. The examined specimens are similar to the Yakutian and the South Siberian ones in having dark grey transverse lines, but differ somewhat from them by more intensive greyish dusting on the wings.

\section{Aspitates taylori sibirica (Djakonov, 1955)}

Aspilates sibirica: Sedykh 1979: 293.

Localities. Kosyrevsk.
Distribution. Subspecies sibirica: Polar Urals, South, Central and East Siberia, Far East (Magadansk Province, Kamchatka Peninsula, Amursk Province, northeast of Khabarovsk Territory), North Mongolia. The other subspecies: North America (Alaska to central Manitoba).

\section{Subfamily Geometrinae}

Geometra papilionaria herbacearia Ménétriès, 1859

Hipparchus papilionaria (Linnaeus, 1758): Djakonov, 1929: 3; Djakonov, 1931: 390; Kurentzov, 1963: 19; Sedykh, 1979: 292.

Geometra papilionaria: Beljaev \& Kuranishi, 2000: 237.

Material examined. 53 males, 3 females: Klyuchi, Kosyrevsk, "Sovhoz Tsentral'nyi" (10 km N of Laso), Shchapino, $17 \mathrm{~km}$ NE of Malki (Poperechnaya River), Paratunka, from 5.VII. to 10.VIII.

Additional localities. Klyuchi, Mil'kovo, Pushchino, Pogranichnyi, Sosnovka, Petropavlovsk-Kamchatskii, Tarja.

Distribution. Subspecies herbacearia: East Siberia (South Evenkiya, Central Yakutia, Transbaikalia), Far East (Magadansk Province, Kamchatka Peninsula, Amursk Province, south of Khabarovsk Territory, Primorsk Territory, Sakhalin Island), China, Korea. The other subspecies: Europe, Caucasus, Transcaucasia, West Siberia, South Kuril Islands, Japan.

Biology. In the Kamchatka Peninsula the species widely inhabits Betula forests in the lowlands and submontane regions.

Remarks. The Kamchatian specimens resemble outwardly those from the Magadansk Province and Yakutia.

\section{Subfamily Sterrhinae}

\section{Timandra rectistrigaria (Eversmann, 1851).}

Timandra puziloi Erschoff 1870: Alpheraky 1897: 340. Timandra rectistrigaria: Staudinger \& Rebel 1901: 279; Djakonov 1929: 4; Djakonov 1931: 390; Sedykh 1979: 292. Timandra rectistrigaria obsoleta Prout 1913: 49, figure 5g; Kurentzov 1963: 27, 51.

Calothysanis rectistrigaria: Viidalepp 1976: 851.

Material examined. 5 males, 3 females: Nachiki, 
Nachiki (Bezymyannoe Lake), Nachikinskoe Zerkal'tse Mt., Nachikinskoe Lake, from 11.VII. to 31 .VII.

Additional localities. Kosyrevsk, Mil'kovo. Kurentzov (1963) noted this species from southwest of the Kamchatka Peninsula (Ust' Bol'sheretskii District) without specific locality.

Distribution. Polar Urals, north of West Siberia, Central and East Siberia (Irkutsk Province, Yakutia), Far East (Magadansk Province, Kamchatka Peninsula, Amursk Province).

Biology. In the Kamchatka Peninsula the species was collected occasionally in the lowland and mountain tundra.

Remarks. The examined specimens are similar to the continental ones and belong to the typical form.

\section{Scopula frigidaria frigidaria (Möschler, 1860)}

Acidalia frigidaria: Alpheraky 1897: 340; Staudinger \& Rebel 1901: 274; Djakonov 1929: 4; Djakonov 1931: 390. Scopula frigidaria: Viidalepp 1976: 849; Sedykh 1979: 292; Beljaev \& Kuranishi 2000: 237.

Scopula frigidaria frigidaria: Viidalepp 1996: 55.

Material examined. 45 males, 22 females: Kichiga River, Elovka River ("Lespromkhoz"), Klyuchi, Azhabach'e Lake (Bushuika River), "Sovhoz Tsentral'nyi" (10 km N of Laso), Laso, Shchapino, $17 \mathrm{~km} \mathrm{NE}$ of Malki (Poperechnaya River), "Khutor, MTS" (Razdol'nyi), Nachiki (Bezymyannoe Lake), Maloe Nachikinskoe Lake, Nachikinskoe Zerkal'tse Mt., Elisovo, Ust'Bol'sheretsk, Paratunka, from 13.VII. to 20.VIII.

Additional localities. Shiveluch volcano, Esso, Aga Mt., Tolbachik Mt., Mil'kovo, Pushchino, Uson volcano, Kikhpinych volcano, "Gornoe Plato", Zhupanovo, Pogranichnyi, Sosnovka, Petropavlovsk-Kamchatskii.

Distribution. Nominotypical subspecies: North Siberia, South Siberia (mountains), Far East (Magadansk Province, Kamchatka Peninsula, north of Amursk Province, central and eastern Khabarovsk Territory), America (Alaska to Newfoundland south to New England, Indiana and British Columbia). The other subspecies: Fennoscandia.

Biology. In the Kamchatka Peninsula the species is common in various types of vegetation from lowlands to the alpine belt.

\section{Subfamily Larentiinae}

Xanthorhoe biriviata angularia (Leech, 1897)

Cidaria (Xanthorhoe) biriviata (Borkhausen, 1794): Djakonov 1929: 10; Djakonov 1931: 402.

Cidaria birivata: Sedykh 1979: 292.

Xanthorhoe biriviata biriviata: Viidalepp 1996: 16.

Material examined. 3 males, "Khutor, MTS" (Razdol'nyi), 17.VI.1958 A. Kurentzov, L. Ivliev \& D. Kononov leg.

Additional localities. Klutshi, Zhupanovo, Petropavlovsk-Kamchatskii.

Distribution. Subspecies angularia: Far East (Kamchatka Peninsula, Amursk Province, south of Khabarovsk Territory, Primorsk Territory, Sakhalin Island, South Kuril Islands), Korea, Japan. The other subspecies: Europe, Caucasus, Transcaucasia, Urals, Siberia (except extreme north).

Biology. In the Kamchatka Peninsula the species is collected occasionally in lowlands.

Remarks. The examined specimens are quite similar to those from the Amur basin and Japan. They differ from the nominotypical European Xanthorhoe biriviata by having a wider and whiter postmedial band on the forewing, by a greater number of black scales on the wings, and by a narrower aedeagus in the male genitalia.

\section{Xanthorhoe rectantemediana (Wehrli, 1927)}

Cidaria (Xanthorhoe) designata (Hufnagel, 1767): Djakonov 1929: 10; Djakonov 1931: 402.

Cidaria designata: Kurentzov 1963: 38; Konovalova 1970: 173: Sedykh 1979: 293.

Xanthorhoe rectantemediana: Viidalepp 1977: 567; Viidalepp 1996: 17; Beljaev \& Kuranishi 2000: 237.

Material examined. 1 female, Severo-Kuril'sk, 21.VII.1964 G. Krivolutzkaja leg., labelled as "Cidaria designata Rott.". 36 males, 15 females: Azhabach'e Lake (Bushuika River), $15 \mathrm{~km}$ NE of Esso (Pravaya Kamchatka River), Mil'kovo, Zhupanovo, $10 \mathrm{~km} \mathrm{~N}$ of Gannaly, $17 \mathrm{~km} \mathrm{NE}$ of Malki (Poperechnaya River), Elisovo, Ust'Bol'sheretsk, Paratunka, Pauzhetka, Shumshu Island, Severo-Kuril'sk, Shelekhov Bay, Ban'chzhou, from 5.VII. to 3.VIII.

Additional localities. Pogranichnyi, Sosnovka, Petropavlovsk-Kamchatskii, Tarja. 
Distribution. Far East (Kamchatka Peninsula, south of Khabarovsk Territory, Primorsk Territory, Sakhalin Island, Kuril Islands), China, Korea, Japan.

Biology. In the Kamchatka Peninsula and on the North Kuril Islands the species widely inhabits various types of vegetation in the lowlands.

Remarks. The Kamchatian specimens are not markedly different from the continental ones. They are easily distinguishable from the closely related European species Xanthorhoe designata by a longer process on the valva and a wider aedeagus with numerous rough cornuti in the male genitalia, and by a conical and shorter antrum in the female genitalia.

\section{Xanthorhoe decoloraria (Esper, 1806)}

Cidaria (Xanthorhoe) munitata (Hübner, 1809): Djakonov 1929: 6; Djakonov 1931: 399; Prout 1937: 123.

Xanthorhoe munitata: Viidalepp 1977: 567.

Xanthorhoe decoloraria: Viidalepp 1996: 15.

Material examined. 1 male originally examined by Djakonov, labelled as follows: "Kamtschatka, Malaise"; "534" and "7631 E94 +".

Localities. Petropavlovsk-Kamchatskii, Tarja.

Distribution. North, Central and Northeast Europe, Caucasus, Transcaucasia, East Kazakhstan, Middle Asia (mountains), Siberia, Far East (Magadansk Province, ?Chukotka, Kamchatka Peninsula, Amursk Province, Sakhalin Island), North America (Alaska to Newfoundland south to New England, Arizona and California).

Remarks. The examined specimen is quite similar outwardly to North European ones. This species is known in the Kamchatka Peninsula only from the two specimens collected by Dr. R. Malaise near Petropavlovsk-Kamchatskii and examined by Djakonov. In spite of subsequent intensive collecting in this area, the species has not been found again in the Peninsula. To judge from the number of collected specimens (1557 individuals), the "Cidaria munitata" of Sedykh (1979) is a misidentification of Xanthorhoe kamtshatica.

Xanthorhoe okhotinaria Beljaev \& Vasilenko, sp. n. (Figs. 2a, b, 3a-d)

Cidaria ferrugata spadicearia (Borkhausen, 1794) [incor- rect authorship]: Alpheraky 1897: 343 [misidentification] Cidaria (Xanthorhoe) spadicearia (Denis \& Schiffermüller, 1775): Djakonov 1929: 9; Djakonov 1931: 402 [misidentification]

Cidaria spadicearia: Djakonov 1929:22; Sedykh 1979: 292. Xanthorhoe spadicearia: Viidalepp 1996: 16.

Type locality. Russia, Kamchatka Peninsula, Middle Avacha River.

Material examined. Holotype. Male, Russia, Kamchatka Peninsula: Middle Avacha River (Pazdol'nyi), 17.VI.1958 A. Kurentzov, L. Ivliev \& D. Kononov leg. (IBSS). Paratypes. 2 males and 6 females. Kamchatka Peninsula: 1 male, 1 female, Nachiki, Nachikinskoe Lake, Nachikinskoe Zerkal'tse Mt., 5, 7.VII.1959 A. Kurentzov, L. Ivliev \& D. Kononov leg.; 1 female, Shchapino, 26.VII.1960 A. Kurentzov, L. Ivliev, D. Kononov \& S. Safronova leg.; 1 female, Middle Kavycha River, 25.VI.1968 O. Kazantsev leg.; 2 females, (Zhupanovo) (Barmotina River), 24.VIII.1973 L. Lobkova leg.; 1 male, 1 female, Azhabach'e Lake (Bushuika River), 13.VII.1996 Yu. Tshistjakov leg. (IBSS, SZMN).

Description. Length of forewing of male and female 9.5-10.5 mm. Palpus long, much longer than diameter of eye. Male antenna bipectinate for $2 / 3$ of its length, after that simple; female antenna simple. Other characters of head are not markedly different from those of Xanthorhoe spadicearia. Wing pattern strongly variable and similar to that of Xanthorhoe spadicearia, but on forewing, postmedial white transverse line less sinuous and less prominent between veins $\mathrm{M}_{2}-$ $\mathrm{Cu}_{1}$; this line usually not very distinct, often yellowish (if so, almost identical to outer yellowish line bordering it. Forewing with ground colour greyish-yellow or greyish-greenish-yellow, sometimes with tinge of pink. Basal, medial and distal areas of the wing usually yellowish-grey or grey because of wide and vague grey transverse sinuous lines covering the ground colour. Hindwing with outer area darkened and with medial area crossed by several indistinct greyish lines. Discal spot on both wings black, distinct, usually large; on hindwing, especially on under side, discal spot usually larger than on forewing.

Male genitalia superficially similar to those of Xanthorhoe spadicearia but can be easily distinguished from the latter by the distal process of costa of valva more slender and distinctly arched 

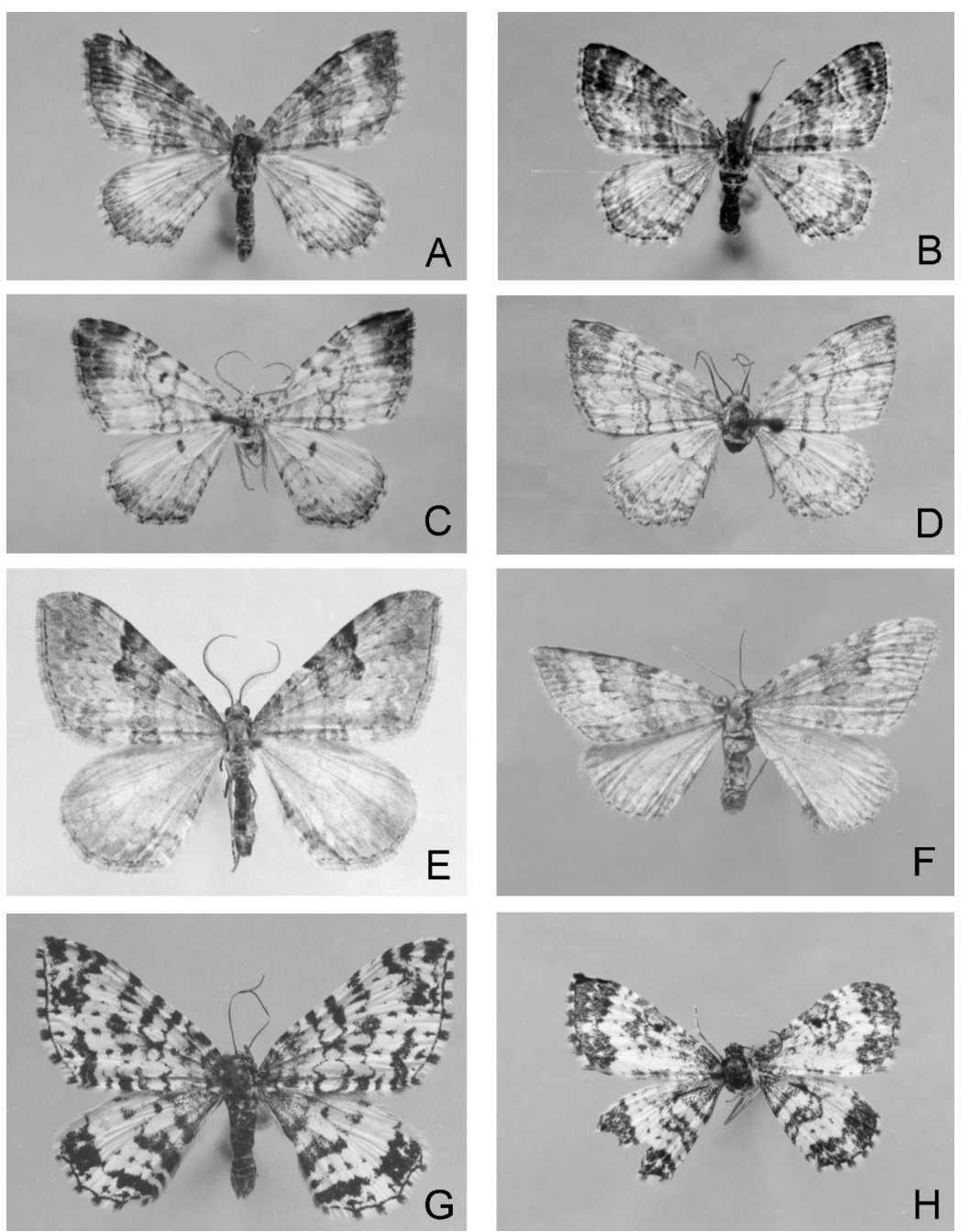

Fig. 2. - a. Xanthorhoe okhotinaria Beljaev \& Vasilenko, sp. n., holotype, male. - b. Xanthorhoe okhotinaria Beljaev \& Vasilenko, sp. n., paratype, female. - c. Xanthorhoe okhotinaria sikhotenaria Beljaev \& Vasilenko, ssp. n., holotype, male. - d. Xanthorhoe okhotinaria sikhotenaria Beljaev \& Vasilenko, ssp. n., paratype, female. - e. Xanthorhoe kamtshatica (Djakonov), male. - f. Xanthorhoe kamtshatica (Djakonov), female, holotype of Cidaria (Xanthorhoe) paramushira Bryk. - g. Rheumaptera subhastata commixta (Matsumura), male, albinistic form. - h. Epirrhoe hastulata reducta (Djakonov), syntype, male.

outwardly in its basal portion, and in the cornutus of the aedeagus having 2 or, rarely, 3 short, triangular spines, whereas in Xanthorhoe spadicearia the cornutus has 4-6 slender, conical spines.

Female genitalia resemble those of Xanthorhoe spadicearia in shape of papillae anales, lamellae ante- and post-vaginalis, ductus bursae and corpus bursae. But they clearly differ in shape of antrum, which in the described species is trapezoid and with length of ventral wall almost equal to or shorter than width of medial part of lamella antevaginalis, whereas in Xanthorhoe spadicearia antrum is broad, cup-like and more than 3 times longer than width of medial part of lamella antevaginalis.

Additional localities. Klyuchi, Nerpich'e Lake, Kosyrevsk, Barmotina River, Pogranichnyi, Petropavlovsk-Kamchatskii.

Distribution. Far East (nominotypical subspecies: Kamchatka Peninsula; the other subspecies: mountains of Primorsk Territory). 


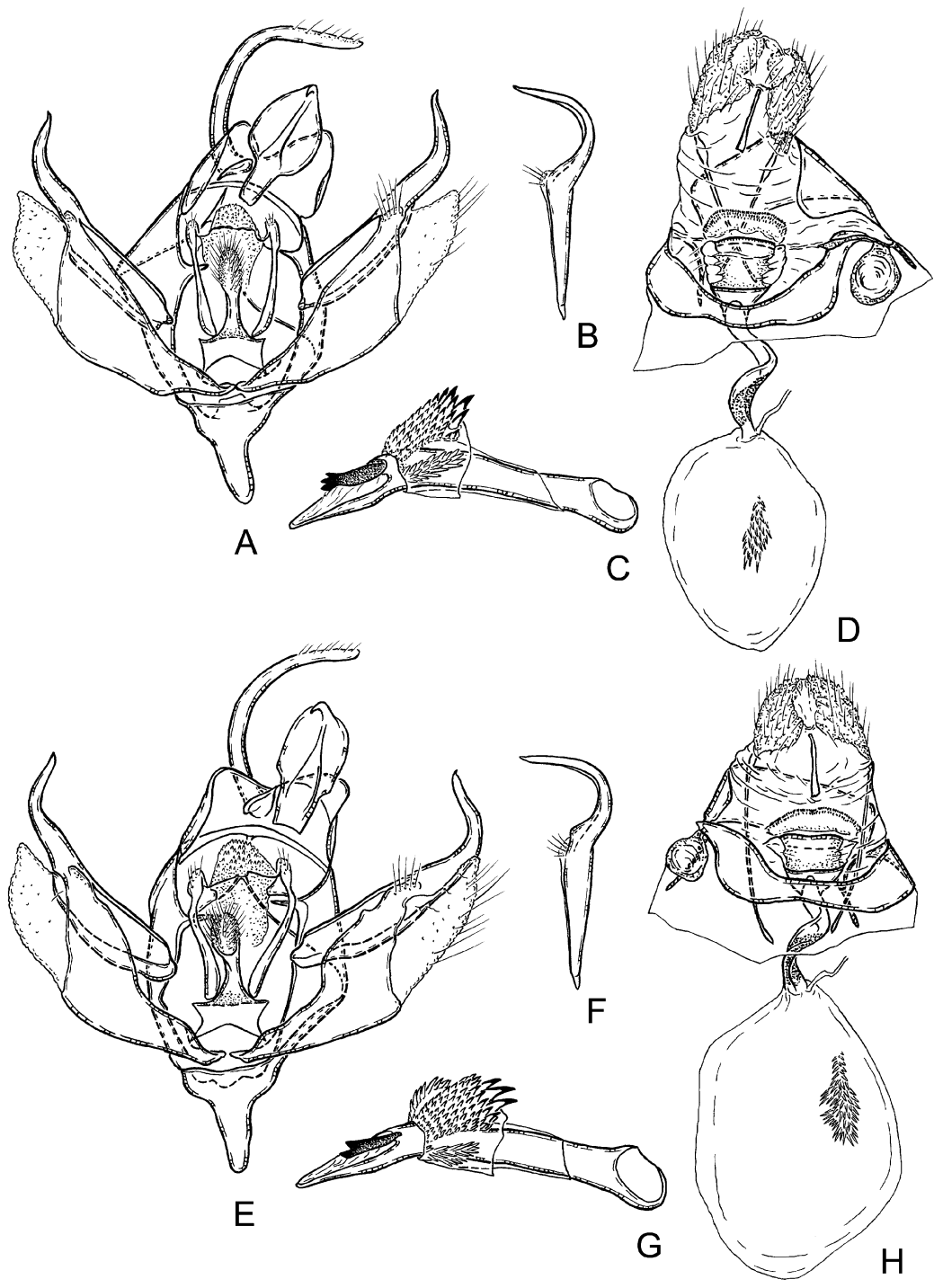

Fig. 3. - a-d. Xanthorhoe okhotinaria okhotinaria Beljaev \& Vasilenko, sp. n. male (holotype) and female (paratype). - eh. Xanthorhoe okhotinaria sikhotenaria Beljaev \& Vasilenko, ssp. n. male (holotype) and female (paratype). a-c, $\mathrm{e}-\mathrm{f}-$ male genitalia $(a, e-$ ventral view, $b, f-$ costa of left valva, dorsal view and $\mathrm{c}, \mathrm{g}$ - aedeagus) and $\mathrm{d}, \mathrm{h}-$ female genitalia.
Biology. In the Kamchatka Peninsula the species widely inhabits various types of vegetation in the lowlands.

Remarks. The described species is compared here with Xanthorhoe spadicearia, the wellknown Euro-Siberian species. However, two other little-known taxa closely related to Xanthorhoe spadicearia occur in South Siberia: Xanthorhoe insperata (Djakonov, 1926) and Xanthorhoe asiatica (Staudinger, 1882). Both taxa are in process of examination by authors of thepresent pa- per, and their taxonomy will be discussed in a separate article. Here, we would like to note only that the new species could not be associated with Xanthorhoe insperata or Xanthorhoe asiatica because of its unique very small antrum and very short spines on the cornutus. Apparently all citations of Xanthorhoe spadicearia in the Kamchatka Peninsula need to be referred to Xanthorhoe okhotinaria. In the Sikhote-Alin' range this species is represented by the subspecies described below. 
Xanthorhoe okhotinaria sikhotenaria Beljaev \& Vasilenko, ssp. n. (Figs. 2c-d, 3e-h)

Type locality. Russia, Primorsk Territory, Dal'negorskii district, $8 \mathrm{~km}$ N of Krasnorechenskii settlement, Podnebesnaya Mt.

Material examined. Holotype. Male, Russia, Primorsk Territory, El'dorado Mt. (Dal'negorskii district, $8 \mathrm{~km} \mathrm{~N}$ of Krasnorechenskii settlement, Podnebesnaya Mt.), 1350 m., 28.VI.1979 V. Vasyurin leg. (IBSS). Paratypes. 2 females. Primorsk Territory: 1 female, "subalpine zone of Lobelaza Mt." (Chuguevskii district, Oblachnaya Mt.), 21.VII.1948 A. Kurentzov leg.; 1 female, El'dorado Mt. (Dal'negorskii district, $8 \mathrm{~km} \mathrm{~N}$ of Krasnorechenskii settlement, Podnebesnaya Mt.), 1350 m., 29.VI.1979 V. Vasyurin leg. (IBSS). Other material: 3 males, heawy damaged, El'dorado Mt. (Dal'negorskii district, $8 \mathrm{~km} \mathrm{~N}$ of Krasnorechenskii settlement, Podnebesnaya Mt.), 1350 m., 29.VI.1979 V. Vasyurin leg.

Description. The new subspecies is somewhat larger than the nominotypical one: length of forewing of male and female 11-12 mm. Forewing with ground colour greyish-pink, sometimes with yellowish hue, medial area with thin and distinct sinuous transverse lines that do not cover ground colour of the wing. The male genitalia are similar structurally to those of the nominotypical subspecies, but more robust. The female genitalia are almost the same as in the nominotypical subspecies, but the antrum is cup-shaped.

Biology. The examined specimens of the new subspecies were collected in mountains in coniferous Abies - Picea forests and in subalpine zone.

\section{Xanthorhoe ferrugata malaisei (Djakonov, 1929)}

Cidaria ferrugata (Clerck, 1759): Alpheraky 1897: 343. Larentia ferrugata: Staudinger \& Rebel 1901: 297. Cidaria (Xanthorhoe) ferrugata malaisei Djakonov 1929: 9, pl. 2, figure 7; Djakonov 1931: 402.

Cidaria ferrugata malaisei Djakonov 1929: 22; Sedykh 1979: 292.

Xanthorhoe ferrugata malaisei: Viidalepp 1977: 567; Viidalepp 1996: 16.

Cidaria unidentaria Haworth 1809: Sedykh 1979: 292

Xanthorhoe ferrugata: Beljaev \& Kuranishi 2000: 237.
Material examined. 29 males, 11 females: Mil'kovo, $10 \mathrm{~km} \mathrm{~N}$ of Gannaly, $17 \mathrm{~km} \mathrm{NE}$ of Malki (Poperechnaya River), "Khutor, MTS" (Razdol'nyi), Nachiki, Nachikinskoe Lake, Nachikinskoe Zerkal'tse Mt., Ust'-Bol'sheretsk, Paratunka, Bol'sheretsk, Severo-Kuril'sk, Ebeko volcano, from 20.VI. to 11.VIII. Magadansk Province: 6 males, 2 females, Ol'skii Island, $45 \mathrm{~km} \mathrm{~N}$. Magadan, Magadanka River near Magadan, Koni Peninsula (Khindzha River), from 2.VII. to 20.VII.

Additional localities. Klutshi, Nerpich'e Lake, Ust'-Kamchatsk, Ust'-Sopochnoe, Ichinskii, Nikolka Mt., Zhupanovo, Pogranichnyi, Petropavlovsk-Kamchatskii.

Distribution. Subspecies malaisei: north of the Far East (south of Magadansk Province - first record, Kamchatka Peninsula, North Kuril Islands). The other subspecies: Europe, Caucasus, Kazakhstan, west of Middle Asia, Siberia (south of Evenkiya, Yakutia, Transbaikalia), North America (Alaska to Newfoundland, south to North Carolina and California).

Biology. In the Kamchatka Peninsula and on the North Kuril Islands the species is common and widely inhabits various types of vegetation from tundra, Betula and Alnus forests in the lowlands to alpine belt with Pinus pumila brushwood and tundra.

Remarks. The examined specimens are extremely variable in size and colouration; some of them are somewhat similar to those of the nominotypical form. The genitalia are variable too; in the male genitalia the distal process of the costa of the valva appears more smoothly arched; in the female genitalia the antrum is somewhat wider than in the nominotypical subspecies.

\section{Xanthorhoe fluctuata (Linnaeus, 1758)}

Cidaria (Xanthorhoe) fluctuata (Linnaeus, 1758): Djakonov 1929: 9; Djakonov 1931: 400.

Xanthorhoe fluctuata: Viidalepp 1977: 567; Viidalepp 1996: 16; Beljaev \& Kuranishi 2000: 237.

Cidaria fluctuata: Sedykh 1979: 292.

Material examined. 1 female, $10 \mathrm{~km} \mathrm{~N}$ of Gannaly, 31.VII.1997 R. B. Kuranishi leg.; 1 female, Petropavlovsk-Kamchatskii (Airport) 23.VIII.1960 A. Kurentzov, L. Ivliev \& D. Kononov leg. 
Additional localities. Aga Mt., Pushchino, Zhupanovo, Pogranichnyi.

Distribution. Europe, Caucasus, Transcaucasia, Asia Minor, North Iran, Middle Asia (mountains), South Siberia, Yakutia, Far East (Kamchatka Peninsula, Kuril Islands: Simushir Isl.), Korea (North), Japan (Honshu, Japan Alps).

Remarks. The examined Kamchatian specimens are markedly different from North European ones in having wider and indistinct white transverse lines on the fore- and hind-wings, more indistinct subapical patch on the forewing, and by a smaller signum with less numerous, shorter spines in the female genitalia. They are similar to both Xanthorhoefluctuata simushira (Bryk, 1942) and Xanthorhoe fluctuata malleola Inoue, 1955. The taxonomy of the East Asiatic populations of the Xanthorhoe fluctuata needs to be studied.

\section{Xanthorhoe derzhavini derzhavini (Djakonov, 1931)}

Cidapla (Xanthorhoe) incursata derzhavini: Djakonov 1931: 400, figure 8 (C).

Cidaria incursata derzhavini: Kurentzov 1963: 25; Sedykh 1979: 292.

Xanthorhoe sajanaria derzhavini: Viidalepp 1977: 567. Xanthorhoe derzavini derzavini [misspelling]: Vasilenko 1995: 665, figures 2, 5, 16.

Xanthorhoe derzhavini: Viidalepp 1996: 16.

Material examined. 1 male, Nachiki (Nachikinskoe Zerkal'tse Mt.), 8.VII.1959 A. Kurentzov, L. Ivliev \& D. Kononov leg.; 1 female, SeveroKuril'sk, 7.VIII.1964 Z. Konovalova, G. Krivolutzkaja \& A. Kupyansklaya leg. Chukotka: 1 male, Chaplino (Goryachie Kluci), 28.VII.1960 A. Kurentzov \& D. Kononov leg. North Koryakiya: 4 males, 2 females, Dezhneva Bay, 13.-20.VII.1991 I. Lyubechanskii leg.

Additional localities. Klyuchevskaya Sopka volcano, Geisernaya River, Zhupanovo, Petropavlovsk-Kamchatskii.

Distribution. Nominotypical subspecies: Polar Urals, North Siberia (Taimyr Peninsula), north of the Far East (Magadansk Province, Chukotka - first record, North Koryakiya, Kamchatka Peninsula, North Kuril Islands — first record). The other subspecies: Central Siberia (East Yakutia), Central part of the Far East (Shantar Islands), Japan (Hokkaido, Daisetsu Mt.).
Biology. In the Kamchatka Peninsula the species inhabits alpine meadows and mountain tundra with Pinus pumila brushwood. On Paramushir Island it was collected in a lowland meadow.

Remarks. Xanthorhoe derzhavini may be conspecific with North American geometrids currently treated as Xanthorhoe incursata (Hübner, 1813), whose distribution in the Old World is limited to Central Europe, based on its facies.

\section{Xanthorhoe kamtshatica (Djakonov, 1929)} (Fig. 2e-f)

Cidaria (Xanthorhoe) kamtshatica: Djakonov 1929: 6, figure 1, plate 2, figure 6; Djakonov 1931: 399; Prout 1937: 123.

Cidaria kamtshatica: Djakonov 1929: 21; Kurentzov \& Ivliev 1960: 99, 102; Kurentzov 1963: 23, 25, 39, 40; Ivliev 1963: 72; Kurentzov 1966: 68; Ivliev 1966: 86; Krivolutzkaja 1973: 210; Sedykh 1979: 292.

Xanthorhoe kamtschatica [misspelling]: Viidalepp 1977: 567; Viidalepp 1996: 15.

Xanthorhoe kamtshatica: Beljaev \& Kuranishi 2000: 238. Cidaria (Xanthorhoe) paramushira Bryk 1942: 78. Xanthorhoe paramushira: Viidalepp 1977: 567.

Cidaria munitata (Hübner, 1809): Sedykh 1979: 292 [misidentification]

Material examined. Type material: Holotype of Cidaria (Xanthorhoe) paramushira Bryk, 1942, female labelled as follows: "Paramushir, Nakodobiai, S. Bergman"; "Typus"; "Nakadobiai, Kureilernu, 25 aug. 1929" (written by hand); "195 76"; "Riksmuseum, Stockholm"; "7754 E94 +" (NHR). Other material: 157 males, 52 females: Azhabach'e Lake (Bushuika River), $15 \mathrm{~km}$ NE of Esso (Pravaya Kamchatka River), Bering Island (Nikol'skoe, Sarannoe Lake), Zhupanovo, "Liman" (Zhupanovo), 10 km N of Gannaly, 17 km NE of Malki (Poperechnaya River), "Khutor, MTS" (Razdol'nyi), Nachiki, Nachikinskoe Lake, Nachikinskoe Zerkal'tse Mt., Ust'-Bol'sheretsk, Vachkazhech Mt., Bol'sheretsk, Shumshu Island (Bol'shoe Lake, Pochtareva Cape, Yaugich Cape,), Severo-Kuril'sk, Shelekhov Bay, Shelekhovka River, Ban'chzhou, Vasilyev Peninsula, from 3.VII. to 28.VIII. Chukotka: 4 males, $30 \mathrm{~km} \mathrm{~N}$ of Providenie (Pestsovaya River), 8., 11., 12.VII.1991 Yu. Tshistjakov leg. Magadansk Province: 1 male, Ol'skii Island (Zavyalova Island), 7.VII.1928; 1 male, Koni Peninsula, 25.VII.1989. 
Additional localities. Klyuchi, Klyuchevskaya Sopka volcano, Aga Mt., Mil'kovo, Uson volcano, Shumnaya River, Kikhpinych volcano, Geisernaya River, "Gornoe Plato", Elisovo, Pogranichnyi, Sosnovka, Petropavlovsk-Kamchatskii.

Distribution. North of the Far East (south of Magadansk Province - first record, east of Chukotka - first record, Kamchatka Peninsula, Komandor Islands, North Kuril Islands).

Biology. In the Kamchatka Peninsula and on Paramushir Island the species is very common and occurs in various types of vegetation from lowlands to alpine belt. Its biology are described by Kurentzov \& Ivliev (Kurentzov \& Ivliev 1960, Kurentzov 1963, Ivliev 1966). The authors note that this species is a characteristic inhabitant of subalpine and alpine belt with brushwood of Pinus pumila, needles of which are eaten by larvae of $X$. kamtshatica (Djakonov) in August. However, this species had been found in the Chukchi Peninsula, outside of the Pinus pumila area. Reared specimens that were examined by Kurentzov \& Ivliev have not been found in the IBSS collection. It is possible that they could be confused with Heterothera taigana (Djakonov), which is somewhat similar to Xanthorhoe kamtshatica and has larvae feeding on Pinus pumila.

Remarks. Until the present time Xanthorhoe kamtshatica was known as endemic to the Kamchatka Peninsula and neighbouring islands, but it has been found on the south coast of the Magadansk Province and in the East Chukotka in forms almost identical to the Kamchatian ones. The species is very variable in wing marking and size, and some of its forms are similar to Xanthorhoe decoloraria (Esper). Possibly, "Cidaria munitata" of Sedykh (1979) is a misidentification of Xanthorhoe kamtshatica, to judge from the number of collected specimens (1557 individuals). The holotype of Cidaria (Xanthorhoe) paramushira (Fig. 2f) is a typical female of Xanthorhoe kamtshatica.

\section{Epirrhoe hastulata reducta (Djakonov, 1929)} (Figs. 2h, 4)

Cidaria tristata (Linnaeus, 1758): Alpheraky 1897: 345; ?Sedykh 1979: 293 [misidentification]

Larentia tristata: Staudinger \& Rebel 1901: 304

Cidaria (Epirrhoë) hastulata reducta: Djakonov 1929:

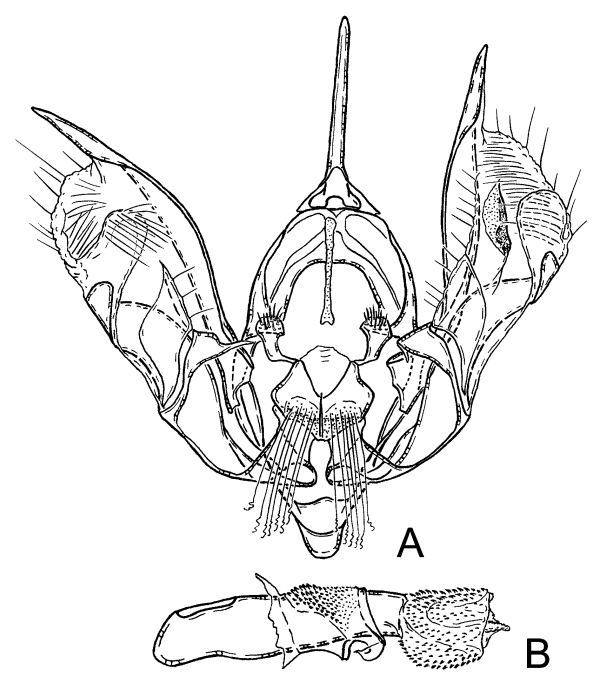

Fig. 4. Epirrhoe hastulata reducta (Djakonov), male, syntype. - a. Male genitalia, ventral view. - b. Aedeagus.

13; Djakonov 1931: 405; Prout 1938: 161.

Cidaria hastulata (Hübner, 1790): Sedykh 1979: 293.

Epirrhoe hastulata reducta: Viidalepp 1977: 569; Viidalepp 1996: 17.

Material examined. Type meterial: syntype of Cidaria (Epirrhoë) hastulata reducta Djakonov, 1929, male labelled as follows: "Kamtschatka, Malaise"; “ 3339”; "Typus"; "Cid. haustulata f. reducta Djak., male, Djakonov det. ”; "8133 E94 +". (NHR).

Localities. Klutchi, Nerpich'e Lake, Zhupanovo, Elisovo, Petropavlovsk-Kamchatskii.

Distribution. Subspecies reducta: Far East (Magadansk Province, Kamchatka Peninsula, Primorsk Territory, Sakhalin Island, Kuril Islands), Japan (Hokkaido). The other subspecies: North, Central and East Europe, Caucasus, Transcaucasia, Kazakhstan, West Siberia, East Siberia (Yakutia, Transbaikalia), North Mongolia, China (Tibet), Japan (Honshu).

Remarks. This subspecies resembles Epirrhoe tristata in having wide white marking on the wings; that could be a cause of the misidentifications cited in the synonymy. The male genitalia of the holotype of the subspecies conform to those of the nominotypical subspecies. Specimens of "Cidaria tristata" noted by Konovalova (1970) from Paramushir Island are in reality Euphyia unangulata renei Bryk, 1949. 


\section{Epirrhoe supergressa (Butler, 1878)}

Cidaria sociata (Borkhausen, 1794): Alpheraky 1897: 343 [misidentification]

Larentia sociata: Staudinger \& Rebel 1901: 302.

Cidaria (Epirrhoë) alternata (Müller, 1764): Djakonov 1929: 13; Djakonov 1931: 405 [misidentification]

Cidaria alternata: Sedykh 1979: 293.

Epirrhoe alternata: Viidalepp 1977: 569.

Epirrhoe supergressa albigressa (Prout, 1938): Viidalepp 1996: 18.

Epirrhoe supergressa: Beljaev \& Kuranishi 2000: 238.

Material examined. 1 female, Klyuchi, 22.VII.1958

A. Kurentzov, L. Ivliev \& D. Kononov leg.; 1 male, Zhupanovo, 5.VIII.1973 L. Lobkova leg.; 1 male, $17 \mathrm{~km}$ NE of Malki (Poperechnaya River), 28.VII.1997 Yu. Tshistjakov leg.

Additional localities. Nerpich'e Lake, Kosyrevsk, Kikhpinych volcano.

Distribution. Transbaikalia, Northeast Siberia, Far East (Kamchatka Peninsula, Amursk Province, south of Khabarovsk Territory, Primorsk Territory, Sakhalin Island, South Kuril Islands), North China, Korea, Japan.

Remarks. The examined Kamchatian specimens differ from subspecies albigressa, from south of the continental Far East, by the blackish proximal and distal areas of the wings and absence of a whitish apical patch. They are quite similar on its facies and in the male and female genitalia to the specimens of Epirrhoe supergressa (Butler 1878) from South Kuril Islands, which resemble the nominotypical form, but Kamchatian specimens are markedly smaller. To clarify the taxonomy of the Kamchatian Epirrhoe supergressa it will be necessary to examine additional material.

\section{Entephria punctipes (Curtis, 1835)}

Cidaria (Dasyuris) polata (Duponchel, 1830): Djakonov 1931: 403; Sedykh 1979: 293 [misidentification?]

Entephria polata byssata (Aurivillius, 1891): Viidalepp 1977: 566

Entephria byssata: Viidalepp 1996: 20.

Localities. Shiveluch volcano, Klyuchevskaya Sopka volcano, Aga Mt., Uson volcano, Kikhpinych volcano.

Distribution. Subarctic Europe, North Siberia, north of the Far East (Magadansk Province,
Chukotka, Kamchatka Peninsula), North America (north-west of Canada, south to Colorado, Greenland).

Biology. In the Kamchatka Peninsula the species was recorded from the alpine belt only.

Remarks. Recently Entephria byssata (Aurivillius) was synonymized with Entephria punctipes (Curtis) in the revision of the genus Entephria Hübner (Troubridge 1997), but the material from the Kamchatka Peninsula was not studied. Whereas the species group polata (Duponchel, 1830), which includes Entephria byssata, contains several close related species occurring in Northeast Asia (Vasilenko 1990), we are unable to conclude about the true species composition in this species group in the Kamchatka Peninsula.

\section{Entephria caesiata (Denis \& Schiffermüller, 1775)}

Cidaria (Entephria) caesiata norvegica (Strand, 1902): Djakonov 1929: 10; Djakonov 1931: 403, 404.

Cidaria caesiata norvegica: Sedykh 1979: 293.

Entephria caesiata: Viidalepp 1996: 20; Beljaev \& Kuranishi 2000: 238.

Material examined. 26 males, 25 females: Kichiga River, Verkhoturov Island, Esso, Shchapino, "Dolina Geiserov" (Geisernaya River), Apacha, 17 km NE of Malki (Poperechnaya River), Maloe Nachikinskoe Lake, Nachikinskoe Zerkal'tse Mt., Vasilyev Peninsula, from 27.VI. to 11.IX. North Koryakiya: 3 females, $20 \mathrm{~km} \mathrm{~W}$ of Tilichiki ("Aiova River" [Avenvayam River], "Mukhomorov Kluch”) 18.-19.VIII.1959 A. Kurentzov, L. Ivliev \& D. Kononov leg.; 1 male, Dezhneva Bay, 13.VII.1991 I. Lyubechanskii leg.

Additional localities. Ust'-Kamchatsk, Klyuchevskaya Sopka Mt., Tolbachik Mt., Nikolka Mt., Uson Volcano, Shumnaya River, Kikhpinych volcano, "Gornoe Plato", Elisovo, Pogranichnyi, Petropavlovsk-Kamchatskii.

Distribution. Europe, Caucasus, Siberia, Far East (Magadansk Province, North Koryakiya first record, Kamchatka Peninsula, mountains of Primorsk Territory, north of Sakhalin Island, North Kuril Islands - first record), North Mongolia, Japan (Honshu).

Biology. In the Kamchatka Peninsula the species inhabits various types of vegetation from low- 
land to alpine belt, but it prefers marshes and tundra.

Remarks. The examined specimens are similar to the North European ones in wing pattern, but darker and with less distinct markings, similar to the wing pattern of the Japanese subspecies nebulosa Inoue, 1955.

\section{Lampropteryx suffumata (Denis \& Schiffer-} müller, 1775)

Cidaria (Lampropteryx) suffumata arctica Sparre-Schneider, 1895 [nom. preocc.]: Nordström 1927: 165, plate 9, figures 21-22; Djakonov 1929: 10; Djakonov 1931: 403.

Cidaria (Lampropteryx) suffumata defumata (Stichel, 1911): Prout 1937: 136

Lampropteryx suffumata defumata: Viidalepp 1977: 573. Cidaria suffumata arctica: Sedykh 1979: 293.

Lampropteryx suffumata: Viidalepp 1996: 27; Beljaev \& Kuranishi 2000: 238.

Material examined. 1 male, $15 \mathrm{~km}$ NE of Esso (Pravaya Kamchatka River), 12.VII.1996 Yu. Tshistjakov leg.

Additional localities. Klyuchi, Ust'-Kamchatsk, Zhupanovo, Elisovo, Pogranichnyi, Petropavlovsk-Kamchatskii.

Distribution. Europe, Caucasus, Transcaucasia, Urals, south of West Siberia (Altai), east of the Far East (Kamchatka Peninsula), Japan (Hokkaido).

Remarks. According to the authors cited above, the subspecies defumata, described from northern Fennoscandia, is recorded from the Kamchatka Peninsula. However, the examined specimen is approximately the same as the nominotypical form in size, whereas the subspecies defumata is half that size, according to the data given in its diagnosis. Therefore it is difficult to consider that the Kamchatian population of Lampropteryx suffumata belongs to the subspecies defumata.

\section{Lampropteryx otregiata Metcalfe, 1917}

Larentia suffumata minna (Butler, 1881): Staudinger \& Rebel 1901: 297 [misidentification]

Cidaria otregiata: Sedykh 1979: 293.

Lampropteryx otregiata: Beljaev \& Kuranishi 2000: 238.

Material examined. 7 males, 1 female: Azhabach'e Lake (Bushuika River), 17 km NE of Malki (Poperechnaya River), Pauzhetka, from 5.VII. to 27.VII.
Additional localities. "Gornoe Plato", Zhupanovo. Distribution. North, Central and East Europe, mountains of South Siberia, Far East (Kamchatka Peninsula, Primorsk Territory, Sakhalin Island, South Kuril Islands), Japan.

Remarks. The Kamchatian specimens are similar to those from the Primorsk Territory and North Europe. A citation of Lampropteryx minna from the Kamchatka Peninsula in Staudinger \& Rebel (1901) evidently should be Lampropteryx otregiata, which is similar to the former.

\section{Eulithis prunata leucoptera (Djakonov, 1929)}

Lygris prunata leucoptera: Djakonov 1929: 5; Djakonov 1931: 398; Prout 1937: 108; Kurentzov 1963: 37; Sedykh 1979: 292; Smetanin 1989: 116

Eulithis prunata leucoptera: Viidalepp 1977: 574; Viidalepp 1996: 24.

Material examined. 2 males, 1 female, Shiveluch volcano, SW slope (Baidarka River), 17.VIII.1958 A. Kurentzov, L. Ivliev \& D. Kononov leg.; 1 male, Shchapino, 10.VIII.1960 V. Minchenko leg.

Additional localities. Kichiga River, Esso, Shumnaya River, Nacihki, Elisovo, PetropavlovskKamchatski.

Distribution. Subspecies leucoptera: Far East (Magadansk Province, Chukotka, Kamchatka Peninsula, Amursk Province, Khabarovsk Territory, mountains of Primorsk Territory, Sakhalin Island, South Kuril Islands), Korea, Japan (Hokkaido). The other subspecies: Europe, Urals, Caucasus, Middle Asia (mountains), West and Central Siberia, Transbaikalia, Yakutia.

Biology. In the Kamchatka Peninsula the species prefers lowland river valleys with Salix, Alnus and Populus forests. Salix sachalinensis is reported as a food plant for larvae of the species in the Peninsula (Smetanin 1989).

Remarks. The examined specimens are similar to those from the Sikhote-Alin Range in the wing pattern, but coloured somewhat paler.

\section{Eulithis testata (Linnaeus, 1761)}

Lygris testata: Sedykh 1979: 292.

Lygris tetsata [misspelling]: Smetanin 1989: 116. 
Material examined. 5 males, Vachkazhech Mt., 25.VIII.1959, Nachiki, 27.VIII.1959, Karaga River, VIII.1959 A. Kurentzov, L. Ivliev \& D. Kononov leg.; 1 female, Zhupanovo, 5.IX.1958 A. Kurentzov, L. Ivliev \& D. Kononov leg.

Additional localities. Kichiga River, Elisovo, Petropavlovsk-Kamchatskii.

Distribution. North, Central and East Europe, Urals, Kazakhstan, Siberia, Far East (Magadansk Province, Kamchatka Peninsula, Amursk Province, south of Khabarovsk Territory, Sakhalin Island), North America (Yukon and British Columbia to Newfoundland, south to New Jersey and Montana).

Biology. In the Kamchatka Peninsula the species prefers tundra in lowland and alpine belt. Salix sachalinensis is reported as a food plant for larvae of the species in the Peninsula (Smetanin 1989).

Remarks. The Kamchatian specimens of Eulithis testata are on average much smaller than specimens of Eulithis populata, unlike the situation in Europe where both species are similar in size.

\section{Eulithis populata (Linnaeus, 1758)}

Lygris populata: Alpheraky 1897: 342; Staudinger \& Rebel 1901: 291; Prout 1914: 212; Djakonov 1929: 5; Djakonov 1931: 398; Kurentzov 1963: 27; Sedykh 1979: 292; Lobkova 1986: 109; Smetanin 1989: 116.

Eulithis populata: Viidalepp 1977: 574; Viidalepp 1996: 25.

Material examined. 72 males, 36 females: Kichiga River, Verkhoturov Island, Karaga River, Karaginskii Island (Oskrnan River, Kayakokkout River), Elovka River ("Lespromkhoz"), Klyuchi, Shchapino (bottom of Nikolka Mt.), Uson volcano, "Dolina Geizerov" (Geisernaya River), Zhupanovo, Nachiki (Bezymyannoe Lake), Nachikinskoe Zerkal'tse Mt., Koryaki, "Middle Avacha River, Khutor, MTS" (Razdol'nyi), Pauzhetka, from 16. VII. to 9. IX. North Koryakiya: 3 males, 1 female, $20 \mathrm{~km} \mathrm{~W}$ of Tilichiki (“Aiova River" [Avenvayam River], "Mukhomornaya Pad"”, "Mukhomorov Kluch") 16., 18.-19.VIII.1959 A. Kurentzov, L. Ivliev \& D. Kononov leg.; 3 males, Tilichiki, 20.VIII.1959 A. Kurentzov, L. Ivliev \& D. Kononov leg.; 2 males, 2 females, Kamenskoe, 7., 10.VIII.1960
L. Ivliev leg. Chukotka: 1 male, Markovo, 16.VIII.1960 A. Kurentzov, L. Ivliev \& D. Kononov leg.

Additional localities. Shiveluch volcano, Upper Raduga River, Esso, Tolbachik Mt., Mashura, Elisovo, Pogranichnyi, Sosnovka, Paratunka, Petropavlovsk-Kamchatskii.

Distribution. Europe, Caucasus, Transcaucasia, Urals, Siberia, Far East (Magadansk Province, Chukotka, North Koryakiya - first record, Kamchatka Peninsula, Amursk Province, south of Khabarovsk Territory, Sakhalin Island), North Mongolia, ?Korea, North America.

Biology. In the Kamchatka Peninsula the species is common and inhabits various types of vegetation, but prefers tundra and marshes in lowland and alpine belt up to $1200 \mathrm{~m}$ above sea level. Salix sachalinensis and Betula ermanii are reported as food plants for larvae of the species in the Peninsula (Lobkova 1986, Smetanin 1989).

Remarks. The Kamchatian specimens are quite similar to the Chukotian and the Magadanian ones, and differ from the North European representatives by somewhat paler coloration.

\section{Ecliptopera silaceata leuca (Djakonov, 1929)}

Cidaria (Euphyia) silaceata deflavata Staudinger, 1871: Djakonov 1929: 11 [misidentification] Cidaria (Euphyia) silaceata leuca: Djakonov 1929: 11, plate 1, figure 3; Djakonov 1931: 404; Prout 1938: 153. Diactinia silaceata leuca: Viidalepp 1977: 574. Cidaria silaceata (Denis \& Schiffermüller, 1775): Sedykh 1979: 293.

Ecliptopera silaceata leuca: Viidalepp 1996: 25. Ecliptopera silaceata: Beljaev \& Kuranishi 2000: 238.

Material examined. 149 males, 55 females: Klyuchi, Azhabach'e Lake (Bushuika River), 15 $\mathrm{km}$ NE of Esso (Pravaya Kamchatka River), Shchapino, Middle Kavycha River, Bogachevka River, Zhupanovo, Semyachinskii Liman (Zhupanovo), $10 \mathrm{~km} \mathrm{~N}$ of Gannaly, $17 \mathrm{~km} \mathrm{NE}$ of Malki (Poperechnaya River), Nachiki, Nachikinskoe Zerkal'tse Mt., "Middle Avacha River, Khutor, MTS” (Razdol'nyi), Elisovo, Paratunka, Bol'sheretsk, Pauzhetka, from 4.VII. to 10.VIII. Additional localities. Pogranichnyi, Paratunka, Tarja.

Distribution. Subspecies leuca: East Siberia (East Sayan Mts, Transbaikalia, Yakutia), Far East 
(Magadansk Province, Kamchatka Peninsula, north of Khabarovsk Territory, Sakhalin Island), Japan. The other subspecies: Europe, Caucasus, Transcaucasia, West and Central Siberia, China (West and Tibet), North America (Alaska to Newfoundland, south to New England, Colorado and California).

Biology. In the Kamchatka Peninsula the species occurs widely from the lowlands to alpine belt, but prefers river valleys with Salix and Alnus forests.

Remarks. The Kamchatian specimens are very variable in size and coloration, from a dark form with narrow yellowish transverse lines (form deflavata Staudinger sensu Djakonov [1929]) to a very light one with wide and indistinct white transverse lines (aberration albomedia Djakonov, 1929). Large specimens of the dark form are superficially similar to specimens of Ecliptopera umbrosaria (Motschulsky, 1861). In the male genitalia the examined specimens are near to nominotypical Ecliptopera silaceata, but they are distinguishable from the latter by a longer aedeagus and a much broader and more rounded saccus. The latter character is diagnostic for Ecliptopera dimita (Prout, 1938) described from West China and Tibet. Prout (1938) determined Ecliptopera silaceata leuca from South Siberia (Sayan Mts) based on the wing markings and noted that the examined specimens have the same shape of male genitalia as those of Ecliptopera dimita. The relationship between nominotypical silaceata, leuca and dimita needs to be reviewed.

\section{Dysstroma citratum kamtshadalarium Beljaev \& Vasilenko, ssp. n. (Figs. 5a-b, 6a-c)}

Cidaria truncata (Hufnagel, 1767): Alpheraky 1897: 342 [misidentification]

Larentia truncata: Staudinger \& Rebel 1901: 293.

Larentia immanata (Haworth, 1809): Staudinger \& Rebel 1901: 293.

Cidaria (Dystroma [misspelling]) citrata (Linnaeus, 1761): Djakonov 1929: 5, 6; Djakonov 1931: 399.

Cidaria citrata: Djakonov 1929: 21; Kurentzov 1963: 25; Sedykh 1979: 292.

Dysstroma citrata conformalis (Prout, 1937): Bryk 1942: 68 [misidentification]

Cidaria (Dystroma [misspelling]) citrata immanata: Konovalova 1970: 174.

?Cidaria infuscata (Tengström, 1869): Lobkova 1986:
110 [misidentification]

Dysstroma citrata subspecies?: Viidalepp 1996: 23.

Type locality. Russia, Kamchatka Peninsula, Nachikinskoe Zerkal'tse Mt.

Material examined. Holotype. Male, Russia, Kamchatka Peninsula, Nachikinskoe Zerkal'tse Mt., 3.VIII.1959 A. Kurentzov, L. Ivliev \& D. Kononov leg. (IBSS). Paratypes, 62 males, 59 females. Kamchatka Peninsula: 21 males, $17 \mathrm{fe}-$ males: "Middle Avacha River, Khutor, MTS" [Razdol'nyi], Klyuchi, Zhupanovo, 27.VII, 1031.VIII, 5-11.IX.1958 A. Kurentzov, L. Ivliev \& D. Kononov leg.; 15 males, 22 females: "Koldun'ya Mt." (Nachiki), Maloe Nachikinskoe Lake, Nachikinskoe Zerkal'tse Mt., Vachkazhech Mt., 31.VII, 1-25.VIII.1959 A. Kurentzov, L. Ivliev \& D. Kononov leg.; 2 females, Karaga River, VIII.1959 A. Kurentzov, L. Ivliev \& D. Kononov leg.; 2 females, Elisovo, 19.VIII.1960 A. Kupanskaya; 2 females, Esso, 23.VIII. 1960 D. Kononov leg.; 3 females, PetropavlovskKamchatskii (Airport), 13.IX.1960 D. Kononov leg.; 11 males, 2 females, Kichiga River, $12-$ 29.VIII.1986 A. Smetanin leg.; 5 females, "Dolina Geiserov" (Geiserhaya River), 2.IX.1987 V. Kirpichnikova leg.; 1 male, Petropavlovsk-Kamchatskii, 14.VIII.1992 O. Kosterin leg.; 1 male, $141 \mathrm{~km} \mathrm{SSW}$ of Petropavlopsk-Kamchatskii, Topkaya River, 27.VIII.1992 O. Kosterin leg. Verkhoturov Island: 5 males, 4 females, 13., 16. \& 26.VIII., 2.IX.1995 A. Smetanin leg. Karaginskii Island: 2 males, Karroura River, Kayakokkout River, 3.IX.1929 V. Razumovskii leg. Komandor Islands: 1 male, Bering Island, 23.VIII.1991 V. Nebaikin leg. Paramushir Island: 1 male, Severo-Kuril'sk, 17.VIII.1964 Z. Konovalova leg. North Koryakiya: 4 males, 20 $\mathrm{km} \mathrm{W}$ of Tilichiki ("Aiova River" [Avenvayam River], "Mukhomorov Kluch") 18.-19.VIII.1959 A. Kurentzov, L. Ivliev \& D. Kononov leg. (IBSS, SZMN). Addition material: Magadansk Province: 3 male, 2 male, $50 \mathrm{~km} \mathrm{~S}$ of Magadan (Ol'skii Island [Zavyalova Island]), 10., 25.\& 29.VIII.1928 G. Dul'keit leg.

Description. Length of forewing 14-17 mm. In general, wing pattern of Kamchatian specimens of Dysstroma citratum is similar to that of the Siberian subspecies septentrionatum (Heydemann, 1929). However, in spite of a great variability in size and wing marking, they differ from the latter 

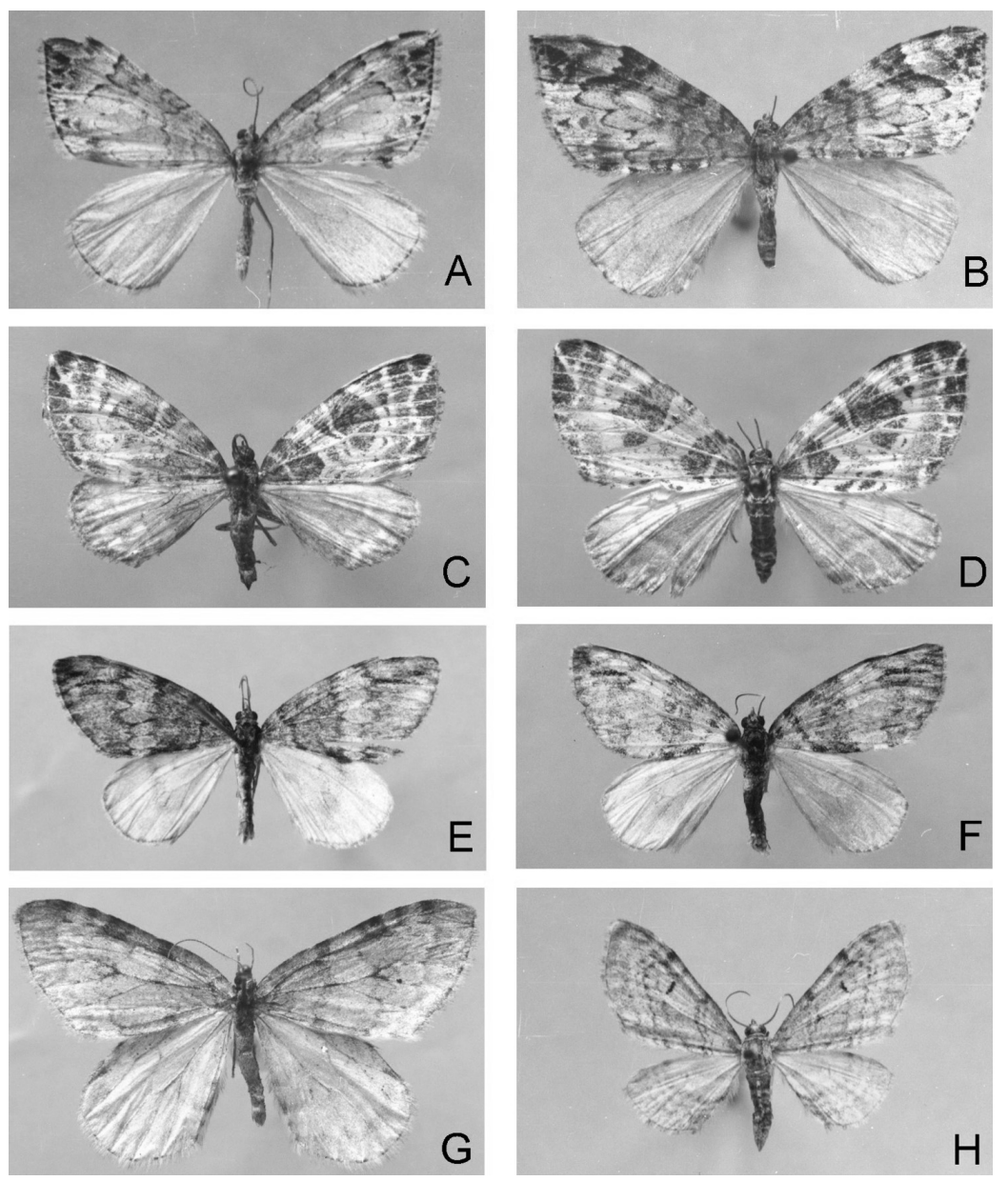

Fig. 5. - a. Dysstroma citratum kamtshadalarium Beljaev \& Vasilenko, ssp. n., holotype, male. - b. Dysstroma citratum kamtshadalarium Beljaev \& Vasilenko, ssp. n., paratype, female. - c. Eustroma reticulatum obsoletum Djakonov, syntype, male. - d. Eustroma reticulatum obsoletum Djakonov, syntype, female. - e. Hydriomena impluviata djakonovi Beljaev, ssp. n., holotype, male. - f. Hydriomena impluviata djakonovi Beljaev, ssp. n., paratype, male. - g. Epirrita autumnata smetanini Beljaev, ssp. n., holotype, male. - h. Eupithecia kurilensis mironovi Beljaev, ssp. n., holotype, male.

in having much paler coloration with a less distinct forewing pattern, in which the light spot before the anterior portion of the postmedial line is almost indistinct; this portion of postmedial line before the bend on the vein $\mathrm{M}_{3}$ usually slightly arched or almost straight, sometimes with 1 or 2 sharp medial projections. The last feature is characteristic for the Dysstroma truncatum species group; that could be a reason for the misidentifications enumerated in the synonymy. The new subspecies is variable in the male and female genitalia, but generally similar to the subspecies septentrionatum, although usually distinguishable by finer cornuti, shorter aedeagus and smaller, laterally more curved corpus bursae. The Siberian and Kamchatian subspecies is readily distinguishable from the nominotypical European Dysstroma citratum by the larger lateral lobe of the anellus and by more slender cornuti in the male genitalia, as well as by a wider antrum in the female genitalia. The examined specimens from the Komandor Islands, the North Kuril Islands and from Zavyalova Island, situated near Magadan, conform well to the Kamchatian ones in wing 
Fig. 6. - a-c. Dysstroma citratum kamtshadalarium Beljaev \& Vasilenko, ssp. n., male (holotype) and female (paratype). $-d-f$. Hydriomena impluviata djakonovi Beljaev, ssp. n., male and female (paratypes). a, b, d, e - male genitalia $(a, d-$ ventral view and $b, e-$ aedeagus) and $\mathrm{c}, \mathrm{f}-$ female genitalia.

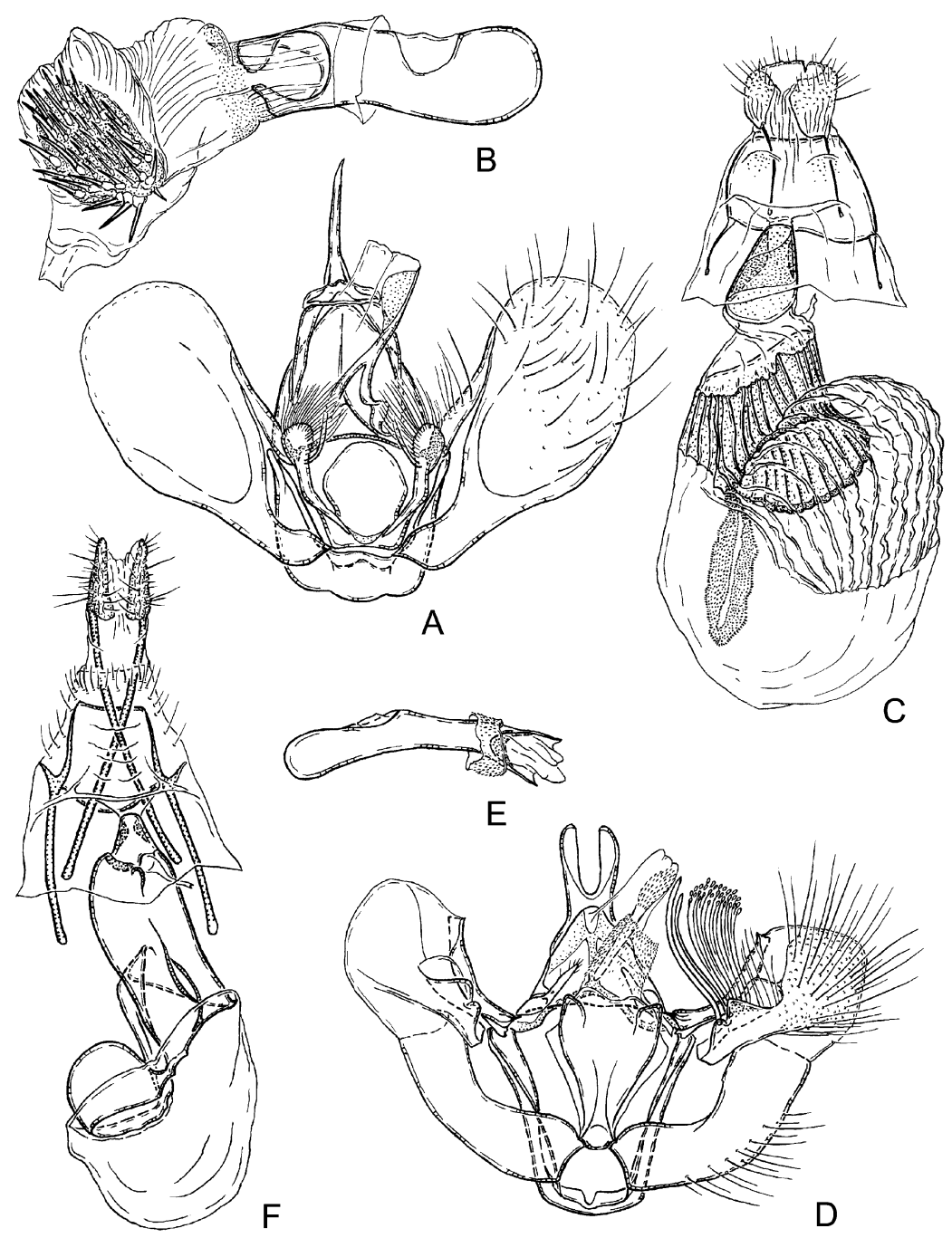

marking and genitalia. The anterior portion of the postmedial line is often straight in the Japanese subspecies conformalis, but the latter differs from the Kamchatian subspecies by its larger size and darker coloration.

Etymology. The subspecies is named after the old Russian name of aborigines of the Kamchatka Peninsula, "Kamchadal".

Additional localities. Shiveluch volcano, Upper Raduga River, Tolbachik Mt., Shchapino, Mashura, Mil'kovo, Uson volcano, Shumnaya River, Kikhpinych volcano, "Gornoe Plato", Kikhchik, Vachkazhech Mt., Pogranichnyi, Sosnovka, Tarja, Ozernovskii, Shumshu Island.

Distribution. Subspecies kamtshadalarium:

north of the Far East (southern coast of Magadansk Province, south of North Koryakiya, Kamchatka Peninsula, Komandor Islands, North Kuril Islands). The other subspecies: Europe, Urals, Caucasus, Transcaucasia, North Kazakhstan, Mongolia, South Siberia, south of the Far East (Amursk Province, south of Khabarovsk Territory, mountains of Primorsk Territory, Sakhalin Island, South Kuril Islands), North Mongolia, China, Tibet, Korea, Japan, North America (Alaska to Newfoundland, south to New England and California).

Biology. In the Kamchatka Peninsula the species is one of the commonest of the geometrid moths. It widely inhabits various types of meadows and forests from lowland tundra to alpine belt. 
Bertula ermanii is reported as a food plant for larvae of Dysstroma infuscatum (Tengström) in the Peninsula (Lobkova 1986), but the last species was probably confused with $D$. citratum (Linnaeus).

\section{Dysstroma infuscatum (Tengström, 1869)}

Cidaria (Dystroma [misspelling]) infuscata (?): Djakonov 1931: 399.

Cidaria infuscata: Sedykh 1979: 292.

Dysstroma infuscata: Viidalepp 1996: 22.

Material examined. 1 female, Nachiki (Nachikinskoe Zerkal'tse Mt.), 21.VIII.1959 A. Kurentzov, L. Ivliev \& D. Kononov leg.; 4 males, 3 females, Bol'sheretsk, 3.-6.VIII.1991 O. Kosterin leg.

Additional localities. Ust'-Kamchatsk, Zhupanovo.

Distribution. North, Central and Northeast Europe, North, Central and East Siberia, Far East (Magadansk Province, Kamchatka Peninsula, Amursk Province, Khabarovsk Territory, mountains of Primorsk Territory, Sakhalin Island), Japan (mountains).

Biology. In the Kamchatka Peninsula the species is found occasionally in the lowland tundra and alpine belt.

Remarks. The examined female from Nachikinskoe Zerkal'tse Mt. is very small in size; the same as that examined by Djakonov (1931). Its genitalia are about half the size of those of North European and Magadanian specimens, but similar in general shape.

\section{Dysstroma pseudimmanatum (Heydemann, 1929)}

Cidaria truncata (Hufnagel, 1767): Sedykh 1979: 292 [misidentification?]

Dysstroma pseudimmanata: Viidalepp 1996: 22; Beljaev \& Kuranishi 2000: 239.

Material examined. 2 males, 11 females: $20 \mathrm{~km} \mathrm{~S}$ of Pushchino (Pravaya Kamchatka River), 17 km NE of Malki (Poperechnaya River), Nachiki, Kuril'skoe Lake, from 7.VII. to 15.VIII. Additional localities. Zhupanovo, Shumnaya River.

Distribution. East Siberia (South Evenkiya,
East Sayan Mts, Transbaikalia), Far East (Magadansk Province, Kamchatka Peninsula, Amursk Province, central part of Khabarovsk Territory), Japan (Honshu, S. Alps).

Biology. In the Kamchatka Peninsula the species is apparently distributed locally in the lowlands and the submontane zones.

Remarks. The examined specimens are markedly larger than the Siberian and Japanese specimens, and they are as pale coloured as the Japanese ones. Dysstroma truncatum was already recorded in the Kamchatka Peninsula as a misidentification of Dysstroma citratum, as was shown by Djakonov (1929). However the "Cidaria truncata" of Sedykh (1979) was collected in July and it cannot be associated with Dysstroma citratum, because the latter flies in the Kamchatka Peninsula in August and September. Probably, the species referred to by him, from Zhupanovo and Shumnaya River, as "Cidaria truncata" is a misidentification of Dysstroma pseudimmanatum, which is somewhat similar to Dysstroma truncatum in wing pattern.

\section{Cidaria luteata Choi, 1998}

Cidaria fulvata (Forster, 1771): Sedykh 1979: 292 [misidentification]

Cidaria fulvata fulvata: Viidalepp 1996: 23.

Cidaria luteata: Choi 1998a: 564, figures 5, 13, 16, 25.

Localities. Esso.

Distribution. South Siberia (Irkutsk Province, Tuva, Transbaikalia), Far East (Kamchatka Peninsula, Khabarovsk Territory).

Remarks. Choi (1998a) supposed that Cidaria fulvata cited from the Kamchatka Peninsula by Sedykh (1979) really belongs to Cidaria luteata.

\section{Thera variata (Denis \& Schiffermüller, 1775)}

Cidaria variata: Sedykh 1979: 292.

Localities. Shumnaya River.

Distribution. Europe, South Siberia (Sayan Mts, Tuva), East Kazakhstan, Northern Mongolia, Far East (Kamchatka, south of Khabarovsk Territory, mountains of Primorsk Territory, Sakhalin Island, South Kuril Islands), Japan. Remarks. The single specimen cited from the 
Kamchatka Peninsula by Sedykh (1979) has not been examined. In the Far East and in Japan there is a subspecies (species?) Thera variata bellisi Viidalepp (1977).

\section{Heterothera taigana sounkeana (Matsumura, 1927)}

Cidaria cognata (Thunberg, 1792): Sedykh 1979: 292 [misidentification?]

Asaphodes taigana (Djakonov, 1926), subspecies?: Viidalepp 1980: 65

Heterothera taigana: Beljaev \& Kuranishi 2000: 239.

Material examined. 1 female, $17 \mathrm{~km}$ NE of Malki (Poperechnaya River), 27.VII.1997 R. B. Kuranishi leg.

Additional localities. Klyuchi, Esso, Elisovo, Petropavlovsk-Kamchatskii.

Distribution. Subspecies sounkeana: Far East (Kamchatka Peninsula, mountains of Primorsk Territory, Sakhalin Island, South Kuril Islands), Japan. The other subspecies: South Siberia (Altai, Sayan and Khamar-Daban Mts, North Baikal region, Buryatia, Transbaikalia), northwest of the Far East (Magadansk Province).

Remarks. The examined specimen has a small signum in the corpus bursae, that is considered by Choi (1998b) as a diagnostic character of the subspecies sounkeana. Evidently, Sedykh (1979) confused this species with the European Thera cognata, which is similar superficially to Heterothera taigana.

\section{Eustroma reticulatum obsoletum Djakonov, 1929 (Fig. 5c-d)}

Eustroma reticulata obsoleta: Djakonov 1929: 5; Djakonov 1931: 398; Prout 1937: 105; Viidalepp 1977: 574; Sedykh 1979: 292.

Eustroma reticulatum obsoletum: Viidalepp 1996: 24.

Material examined. Type material: syntypes of Eustroma reticulata obsoleta Djakonov, 1929: male, labelled as follows: "Kamtschatka, Malaise"; " 1286"; "Typus"; "Eustroma reticulata f. obsoleta Djak., male, Djakonov det. ”; “9539 E94 +"; female, labelled as follows: "Kamtschatka, Malaise"; “ 1957”; "Alloypus"; "Eustroma reticulata f. obsoleta Djak., female, Djakonov det.
"; “9541 E94 +". (NHR).

Localities. Shchapino, Zhupanovo, Pogranichnyi, Petropavlovsk-Kamchatskii.

Distribution. Subspecies obsoletum: east of the Far East (Kamchatka Peninsula). The other subspecies: Europe, West and Central Siberia, North Mongolia, south of the Far East (Amursk Province, south of Khabarovsk Territory, Primorsk Territory, Sakhalin Island, South Kuril Islands), China, Korea, Japan.

Remarks. The type specimens of obsoletum differ from the European and East Asiatic ones of E. reticulatum (Denis \& Schiffermüller, 1775) by their very wide white lines on the forewing. They are reminiscent of the albinistic Kamchatian specimens of Ecliptopera silaceata leuca belonging to the genus closely related to Eustroma (Hübner, 1825). It is possible, the type specimens of obsoletum Djakonov is an albinistic form only, but at present we have no basis for supportting Inoue's opinion about the synonymy of $E$. reticulatum obsoletum and E. reticulatum chosenicola Bryk, 1949 (Inoue 1977).

\section{Colostygia aptata (Hübner, 1813)}

Cidaria (Calostigria) aptata: Djakonov 1929: 10; Djakonov 1931: 403.

Colostygia aptata: Viidalepp 1977: 573; Viidalepp 1996: 21; Beljaev \& Kuranishi 2000: 239.

Cidaria aptata: Sedykh 1979: 293.

Material examined. 9 males, 1 female: Elovka River (“Lespromkhoz"), "Klyuchi Mt.” [Zhupanovo], 17 km NE of Malki (Poperechnaya River), Nachiki, Nachikinskoe Lake, Elisovo, from 3.VII. to 16.VIII. Additional localities. Kluci, Mil'kovo, Shumnaya River, Pogranichnyi, Petropavlovsk-Kamchatskii, Tarja.

Distribution. Europe (except extreme North), South Siberia, Yakutia, Far East (Kamchatka Peninsula, Amursk Province, Sakhalin Island), North Mongolia.

Biology. In the Kamchatka Peninsula the species prefers Betula and Larix forests in submontane zones.

Remarks. The examined specimens are similar to North European ones in size and wing pattern, but slightly lighter and with less distinct transverse sinuous striation. 


\section{Colostygia turbata altaicata Djakonov, 1926}

Cidaria (Calostigia) turbata altaicata Djakonov, 1926: Djakonov 1931: 403.

Cidaria turbata altaicata: Sedykh 1979: 293.

Colostygia turbata altaicata: Viidalepp 1996: 22.

Material examined. 1 male, Upper Icha River, 1.5.VI.1991 A. Martyinenko leg.

Additional localities. Nerpich'e Lake, Zhupanovo.

Distribution. Subspecies altaicata: South Siberia (Altai, Sayan Mts, Buryatia), east of the Far East (Kamchatka Peninsula). The other subspecies: Central (mountains), North and Northeast Europe, North Urals, North America (Canada).

Biology. The species is apparently rare in the Kamchatka Peninsula.

Remarks. The examined specimen conforms well to the diagnosis of the subspecies altaicata.

\section{Hydriomena furcata (Thunberg, 1784)}

Cidaria (Hydriomene [misspelling]) furcata Fabricius [incorrect authorship]: Djakonov 1929: 14; Djakonov 1931: 406.

Cidaria furcata Fabricius [incorrect authorship]: Kurentzov 1963: 38.

Hydriomena furcata: Viidalepp 1977: 571; Viidalepp 1996: 21.

Cidaria furcata: Sedykh 1979: 293.

Cidaria ruberata (Freyer, 1831): Sedykh 1979: 293; Viidalepp 1996: 21 [misidentification?]

Cidaria furcata Donovan [incorrect authorship]: Smetanin 1989: 116.

Material examined. 9 males, 1 female: Kichiga River, Elovka River, "Lespromkhoz", Laso, "Dolina Geizerov" (Geisernaya River), Bogachevka River, Zhupanovo, "Khutor, MTS" [Razdol'nyi], Petropavlovsk-Kamchatskii, from 14.VIII to 9.IX.

Additional localities. Esso, Tolbachik Mt., Shchapino, Vachkazhech volcano, Elisovo, Pogranichnyi.

Distribution. Europe, Caucasus, Transcaucasia, Urals, Kazakhstan, West Siberia, East Siberia (Transbaikalia, Yakutia), Far East (Magadansk Province, Kamchatka Peninsula, ?Amursk Province, ?Khabarovsk Territory, mountains of Primorsk Territory, Sakhalin Island, South Kuril Islands), East Kazakhstan, North Mongolia,
China, Korea, Japan, North America (Alaska to Newfoundland, south to British Columbia).

Biology. Salix sachalinensis is reported as the food plant for larvae of the species in the Peninsula (Smetanin 1989).

Remarks. The Kamchatian specimens differ markedly from the nominotypical form and from the Japanese subspecies nexifasciata (Butler, 1881). On their facies they are closest to the East Siberian specimens of the species from Yakutia, Magadansk Province and Transbaikalia. The problem with the subspecific name of this taxon is still unresolved. Apparently, Sedykh (1979) confused some specimens of $H$. furcata with West Palaearctic Hydriomena ruberata.

\section{Hydriomena impluviata djakonovi Beljaev, ssp. n. (Figs. 5e-f, 6d-f)}

Cidaria (Hydriomene [misspelling]) coerulata (Fabricius, 1776): Djakonov 1929: 14, 22, plate 1, figure 2; Djakonov 1931: 406; Prout 1938: 170.

Hydriomena coerulata: Viidalepp 1977: 571; Viidalepp 1996: 21.

Cidaria coerulata: Sedykh 1979: 293.

Cidaria autumnalis (Ström, 1783): Lobkova 1986: 110. Hydriomena impluviata (Denis \& Schiffermüller, 1775): Beljaev \& Kuranishi 2000: 239.

Type locality. Russia, Paramushir Island, Shelekhov Bay.

Material examined. Holotype. Male, Russia, Paramushir Island, Shelekhov Bay, 17.VII.1997 E. Makarchenko \& S. Kholin leg. (IBSS). Paratypes, 34 males, 30 females. Kamchatka Peninsula: 2 males, 1 female, Mil'kovo, 20.-21.VI.1958 A. Kurentzov, L. Ivliev \& D. Kononov leg.; 1 male, 1 female, Nachiki, 5, 18.VII.1959 D. Kononov leg.; 1 male, 1 female, Shchapino, 4 , 20.VII.1960 A. Kupanskaya \& S. Safronova leg. leg.; 1 female, (Zhupanovo) ex pupa 24.VI.1973 L. Lobkova leg.; 3 males, 1 female, (Zhupanovo, 1973) L. Lobkova leg.; 3 males, 6 females: Pauzhetka, Paratunka, 9, 19.VII.1976 V. Kirpichnikova leg.; 3 males, 1 female: 17 km NE of Malki (Poperechnaya River), 5.VII.1996, Azhabach'e Lake (Bushuika River), 13.VII.1996 Yu. Tshistjakov leg. Karaginskii Island: 1 female, 17.VII.1963 A. Kurentzov. Shumshu Island: 2 males, 2 females, Bol'shoe Lake, 21.-22.VII.1997 
R. B. Kuranishi leg.; 1 female, ditto., 22.VII.1997 E. Makarchenko \& S. Kholin leg. Paramushir Island: 9 males, 12 females, Severo-Kuril'sk, 19.VII.-3.VIII.1964 N. Azarova, Z. Konovalova leg., G. Krivolutzkaja \& A. Kupyansklaya leg.; 7 males, 1 female: Severo-Kuril'sk, 11, 5.VII.1997, Shelekhov Bay, 17.VII.1997 R. B. Kuranishi leg.; 1male, 1 female, Shelekhov Bay, 17.VII.1997 E. Makarchenko \& S. Kholin leg. (IBSS).

Description. Length of the forewing 11$15 \mathrm{~mm}$. The Kamchatian specimens are variable in intensity of wing colouration, from pale, almost albinistic, to very dark, but the general colour of the forewing is always grey, without green or yellow hue on the bands. They differ distinctly from the European nominotypical $H$. impluviata by a very wide antemedial band on the forewing, narrowing only slightly posteriorly, bordered with almost straight antemedial and basal transverse lines. The newly described subspecies is distinguishable from the Far Eastern continental and Sakhalinian specimens by a zigzag postmedial transverse line and narrow, dark, monochrome subbasal line on the forewing. In the male genitalia, the new subspecies is separable from both European and continental Far Eastern representatives by the wider neck of the uncus and by the deeper incision between its forks, and in the female genitalia by the sclerotization of the neck of the corpus bursae being less stretched anteriorly along its left side; in consequence the distance between the neck of the corpus bursae and the bubble-like inflation (digitabulum McDunnough, 1954 ) is shorter. On the basis of the shape of uncus and corpus bursae, the described subspecies somewhat resembles the North American species Hydriomena renunciata (Walker, 1862). However, it differs from the latter (in comparison with description and figures in McDunnough, 1954)in that the postmedial transverse lines on the forewing are less prominent outwardly between veins $\mathrm{M}_{3}-\mathrm{Cu}_{2}$, and in the genitalia, in having a shorter uncus without long apical setae on the ventral sides of its forks, in the absence of cornuti in the aedeagus, and in the larger bubble-like inflation of the corpus bursae, with or without very short spines on its basal edge.

Etymology. The subspecies is named after Dr. A. M. Djakonov, one of the most noted special- ists of the geometrid moths.

Additional localities. Klyuchi, Ust'-Sopochnoe, Ichinskii, Shumnaya River, Pogranichnyi, Petropavlovsk-Kamchatskii.

Distribution. Subspecies djakonovi: east of the Far East (Kamchatka Peninsula, North Kuril Islands). The other subspecies: Europe, Turkey, Urals, Middle Asia (mountains), south of West Siberia, west and south of the Far East (Magadansk Province, Amursk Province, Khabarovsk Territory, Primorsk Territory, Sakhalin Island, South Kuril Islands), North Mongolia, North China, Korea, Japan.

Biology. In the Kamchatka Peninsula and on the North Kuril Islands the species widely inhabits various types of forests in the lowlands and submontane zones. Betula ermanii, Alnus hirsuta and Salix spp. are reported as food plants for larvae of the species in the Peninsula (Lobkova 1986).

Remarks. A pale-coloured form of the new subspecies has been described as abberation marmorata Djakonov, 1929 (infrasubspecific name).

\section{Coenocalpe lapidata (Hübner, 1809)}

Cidaria lapidata: Alpheraky 1897: 346.

Phibalapteryx lapidata: Staudinger \& Rebel 1901: 321. Coenocalpe lapidata: Djakonov 1929: 19; Djakonov 1931: 408; Viidalepp 1977: 570; Viidalepp 1996: 32; Sedykh 1979: 293.

Material examined. 38 males, 8 females: Kichiga River, Elovka River ("Lespromkhoz"), Esso, Shchapino, Nachikinskoe Zerkal'tse Mt., "Khutor, MTS" (Razdol'nyi), from 27.VII. to 11.IX.

Additional localities. Klyuchi, Tolbachik Mt., Mashura, Mil'kovo, Elisovo, Pogranichnyi, Petropavlovsk-Kamchatskii.

Distribution. Europe, North Siberia south to Altai and Sayan Mts, Far East (Kamchatka Peninsula, Amursk Province), North Mongolia.

Biology. In the Kamchatka Peninsula the species occurs in various types of vegetation in the lowlands and in submontane zones.

Remarks. The Kamchatian specimens are similar to the North European ones in the wing pattern, but differ in the darker ground colour of the wings. 
Spargania luctuata albidior (Alpheraky, 1897)

Cidaria luctuata albidior: Alpheraky 1897: 344.

Larentia lugubrata albidior: Staudinger \& Rebel 1901: 303. Cidaria (Euphyia) luctuata albidior: Prout 1914: 248, plate 10d; Djakonov 1929: 11; Djakonov 1931: 404; Viidalepp 1977: 565.

Cidaria luctuata albidor: Sedykh 1979: 293.

Spargania luctuata albidor: Viidalepp 1996: 20.

Spargania luctuata (Denis \& Schiffermüller, 1775): Beljaev \& Kuranishi 2000: 239.

Material examined. 18 males, 8 females: Klyuchi, Azhabach'e Lake (Bushuika River), $15 \mathrm{~km} \mathrm{NE}$ of Esso (Pravaya Kamchatka River), Laso, Shchapino, Middle Kavycha River, $20 \mathrm{~km} \mathrm{~S}$ of Pushchino (Pravaya Kamchatka River), Zhupanovo, 10 km N of Gannaly, 17 km NE of Malki (Poperechnaya River), Nachiki, Nachikinskoe Lake, Nachikinskoe Zerkal'tse Mt., Koryaki, from 25.VI. to 3.VIII.

Additional localities. Nerpich'e Lake, Shumnaya River, Elisovo, Pogranichnyi, Sosnovka, Petropavlovsk-Kamchatskii.

Distribution. Subspecies albidior: East Siberia (Central Yakutia), north of the Far East (Magadansk Province, Kamchatka Peninsula). The other subspecies: North, Central and East Europe, West Siberia, mountains of South Siberia, Transbaikalia, south of the Far East (Amursk Province, south of the Khabarovsk Territory, mountains of Primorsk Territory, Sakhalin Island), North America (Alaska to Newfoundland, south to New England and British Columbia).

Biology. In the Kamchatka Peninsula the species is common in various types of vegetation from the lowland forests to alpine belt.

Remarks. The Kamchatian specimens are quite similar to the Magadanian ones.

\section{Rheumaptera hastata (Linnaeus, 1758)}

Cidaria hastata: Alpheraky 1897: 345 (part); Kurentzov 1963: 37; Sedykh 1979: 293.

Cidaria (Eulype) hastata: Djakonov 1929: 12; Djakonov 1931: 405.

Larentia hastata: Efremova \& Vakulenko 1971: 253. Rheumaptera hastata: Viidalepp 1977: 570; Viidalepp 1996: 30 .

Material examined. 16 males, 19 females: Klyuchi, Kosyrevsk, Shchapino, Mil'kovo, 40 km NE of Mil'kivo (Kirganik River, "Bichki”), Middle
Kavycha River, Shumhaya River, Nachiki, Nachikinskoe Lake, Paratunka, Bol'sheretsk, from 22.VI. to 13.VIII. Chukotka: 1 female, Chaplino (Goryachie Klushi), 25.VI.1958 A. Kurentzov, L. Ivliev \& D. Kononov leg.

Additional localities. Zarechnyi range, Nerpich'e Lake, Klyuchevskaya Sopka volcano, Esso, Zhupanovo, Koryaki, Pogranichnyi, Sosnovka, Russkaya Bay.

Distribution. Europe, Siberia, Far East (Magadansk Province, Chukotka - first record, Kamchatka Peninsula, Amursk Province, Khabarovsk Territory, Primorsk Territory, Sakhalin Island, South Kuril Islands), North Kazakhstan, North Mongolia, China, Korea, Japan (Hokkaido), North America (Alaska to Newfoundland, south to south to northern California, New Mexico and North Carolina).

Biology. In the Kamchatka Peninsula the species is widely distributed in Betula forests. Betula platyphylla is reported as a food plant for larvae of the species in the Peninsula (Efremova \& Vakulenko 1971).

Remarks. The Kamchatian specimens are quite similar to the East Siberian ones, but more variable; one of the examined specimens has very narrow black markings on the wings, resembling a light form of Rheumaptera subhastata commixta.

\section{Rheumaptera subhastata commixta (Matsumura, 1925) (Fig. 5g)}

Cidaria hastata (Linnaeus, 1758): Alpheraky 1897: 345 (part); Konovalova 1970: 174; Krivolutzkaja, 1973: 216 [misidentification]

Larentia hastata subhastata (Nolcken, 1870): Staudinger \& Rebel 1901: 303.

Cidaria (Eulype) subhastata clarior: Djakonov 1929:

12, plate 1, figure 1; Djakonov 1931: 405; Prout 1938: 160. Cidaria (Eulype) subhastata: Djakonov 1931: 405.

Cidaria subhastata: Konovalova 1970: 174; Sedykh 1979: 293.

Rheumaptera subhastata: Viidalepp 1977: 570; Beljaev \& Kuranishi 2000: 239.

Rheumaptera subhastata clarior: Viidalepp 1977: 570. Rheumaptera hastata rikovskensis (Matsumura, 1925):

Viidalepp 1977: 570 [misidentification?]

Rheumaptera subhastata commixta (Matsumura, 1925): Viidalepp 1996: 30.

Material examined. 1 female, Severo-Kuril'sk, 21, 27.VII.1964 N. Azarova leg., labelled as "Larentia 
(Cidaria) hastata Linne"; 1 male, Shelekhov Bay, Ban'chzhou, 22.VIII.1964 G. Krivolutzkaja leg., labelled as "Larentia subhastata L.". 14 male, 11 females: Karaginskii Island, Pyschino, Zhupanovo, 17 km NE of Malki (Poperechnaya River), Nachiki, Nachikinskoe Lake, Elisovo, Paratunka, Pauzhetka, Severo-Kuril'sk, Shelekhov Bay, from 1.VII. to 27.VII. North Koryakiya: 4 males, Dezhneva Bay, 13.VII.1991 I. Lyubechanskii leg. Magadansk Province: 1 male, $5 \mathrm{~km}$ WSW of Palatka (Khasyn River), 3.VII.1972 E. Matis leg.

Additional localities. Upper Raduga River, Klyuchi, Kosyrevsk, Klyuchevskaya Sopka volcano, Petropavlovsk-Kamchatskii, Tarja.

Distribution. Subspecies commixta: Far East (Magadansk Province, North Koryakiya, Kamchatka Peninsula, Sakhalin Island, North Kuril Islands). The other subspecies: North, Central and Northeast Europe, North Siberia south to Altai, Yakutia, south of the Far East (?Amursk Province), North Mongolia, North America (Alaska to Newfoundland, south to northern California, Colorado and North Carolina).

Biology. In the Kamchatka Peninsula this species widely inhabits Betula and Alnus forests in the lowlands and submontane zones, but occurs in the alpine belt too. It is more common in the south part of the Peninsula and on Paramushir Island than in the central part. Alnus sp. is reported as a food plant for larvae of Rheumaptera hastata on Paramushir Island (Krivolutzkaja 1973), but that species was confused with Rheumaptera subhastata.

Remarks. In the Kamchatka Peninsula the form clarior (in Djakonov's original concept the form is characterised by albinistic colouration of the wings) occurs together with a form similar to the typical one. The albinistic form is common in the south and east of the Peninsula, as well as on the neighbouring islands, and the typical one is more often noted in the central part of the Peninsula. However, Kamchatian, Magadanian and Sachalinian specimens of Rheumaptera subhastata can be distinguished from European and South Siberian ones by: larger size, narrower black marking on the wings (especially in the medial area of the forewing), and (on the fore- and hind-wings) postmedial white band with black dots not connected to each other by a line of black scales. The male genitalia of the moths from the Kamchatka Pe- ninsula and Magadanian Province conform well to those of the holotype of Rh. subhastata commixta (see Sato 2001). Therefore, we support the synonymy of Cidaria (Eulype) subhastata clarior Djakonov, 1929, with Cidaria (Epirrhoe) subhastata commixta Matsumura, 1925, proposed with question by Viidalepp (1996), and treatment of populations of Rheumaptera subhastata, from the Magadansk Province, North Koryakiya, Kamchatka Peninsula, Sakhalin Island and North Kuril Islands, as subspecies Rheumaptera subhastata commixta. Some darkest specimens of the discussed subspecies are very similar to Rheumaptera hastata, and they cannot be distinguished with certainty from the latter on its facies. Apparently, note of Rheumaptera hastata rikovskensis from Paramushir Island by Viidalepp (1977) is a misidentification of the dark form of Rheumaptera subhastata commixta.

\section{Euphyia unangulata renei Bryk, 1949}

Cidaria unangulata (Haworth, 1809): Alpheraky 1897: 344; Kurentzov 1963: 38; Sedykh 1979: 293.

Larentia unaugulata: Staudinger \& Rebel 1901: 302. Cidaria (Euphyia) unangulata: Djakonov 1929: 10; Djakonov 1931: 404.

Euphyia unangulata gracilaria (Bang-Haas, 1906): Viidalepp 1977: 571.

Euphyia unangulata renei: Bryk 1949: 175; Viidalepp 1996: 17.

Cidaria tristata (Linnaeus, 1758): Konovalova 1970: 174 [misidentification]

Euphyia unangulata: Beljaev \& Kuranishi 2000: 240.

Material examined. 1 female, Ban'chzhou, 22.VII.1964 G. Krivolutzkaja leg., with label written by hand "Cidaria tristata? L.". 79 males, 28 females: Azhabach'e Lake (Bushuika River), 15 $\mathrm{km}$ NE of Esso (Pravaya Kamchatka River), Laso, Shchapino, Mil'kovo, $40 \mathrm{~km}$ NE of Mil'kivo (Kirganik River, "Bichki”), Middle Kavycha River, $20 \mathrm{~km} \mathrm{~S}$ of Pushchino (Pravaya Kamchatka River), Zhupanovo, $10 \mathrm{~km}$ N of Gannaly, $17 \mathrm{~km}$ NE of Malki (Poperechnaya River), Nachiki, Nachikinskoe Lake, "Middle Avacha River, Khutor, MTS" (Razdol'nyi), Ust'-Bol'sheretsk, Pauzhetka, Severo-Kuril'sk, Ban'chzhou, from 17.VI. to 1. VIII.

Additional localities. Zarechnyi range, Klyuchi, Ushki, Kosyrevsk, Ust'-Sopochnoe, Ichinskii, 


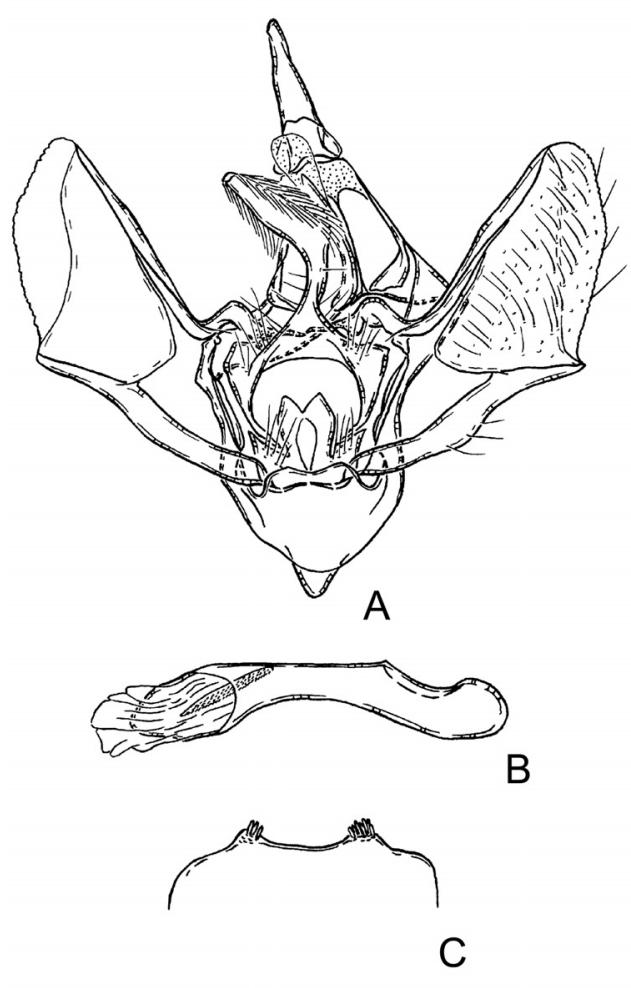

Koryaki, Elisovo, Pogranichnyi, PetropavlovskKamchatskii.

Distribution. Subspecies renei: east of the Far East (Kamchatka Peninsula, North Kuril Islands). The other subspecies: Europe, West Siberia, South Siberia, west and south of the Far East (Magadansk Province, Amursk Province, Khabarovsk Territory, Primorsk Territory, Sakhalin Island, South Kuril Islands), North China, Korea (North), Japan (Hokkaido), North America.

Biology. In the Kamchatka Peninsula the species is common and widely inhabits the Betula, Alnus and Larix forests in the lowlands and submontane zones.

Remarks. The Kamchatian specimens differ from those occurring in the south of the Far East (subspecies gracilaria) in the less contrasted marking of the forewing, and in the distinct, dark, wide terminal band of the hindwing. The subspecies renei is distinguishable from the European nominotypical subspecies by usually darker medial and basal areas of the forewing, and by strongly reduced white spots on the terminal area

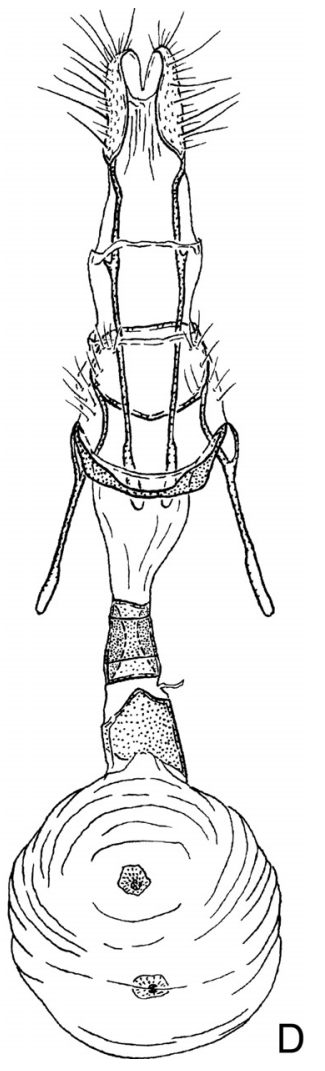

Fig. 7. Epirrita autumnata smetanini Beljaev, ssp. n., male and female, paratypes. - a. Male genitalia, ventral view. - b. Male genitalia, aedeagus. $-\mathrm{c}$. Posterior margin of VIII sternite of male abdomen. - d. Female genitalia.

of the fore- and hind-wings. But in general it is very close to the European form.

Epirrita autumnata smetanini Beljaev, ssp. n. (Figs. 5g, 7)

Oporinia autumnata (Borhausen, 1794): Djakonov 1929: 5; Djakonov 1931: 398; Sedykh 1979: 292; Kurentzov 1963: 38; Lobkova 1986: 106.

Oporinia autumnata valbergi: Smetanin 1989: 116 [nomen nudum (misspelling of the name of the aberration sandbergi Lampa, 1885?)]

Type locality. Russia, Bering Sea, Karaginskii Island north-east of the Kamchatka Peninsula.

Material examined. Holotype. Male, Russia, Karaginskii Island, (1929) V. Razumovskii leg. (IBSS). Paratypes, 7 males, 4 females. Kamchatka Peninsula: 1 male, 2 females, Kronotskii Reserve, Barmotina River, 2.XI.1973 L. Lobkova leg.; 6 males, 2 females, Kichiga River, 16, 26, 27.IX.1986 A. Smetanin leg. Other material. Magadansk Province: 1 male, $50 \mathrm{~km} \mathrm{~S}$ of Magadan (Ol'skii Island 
[Zavyalova Island]), 29.VIII.1928 G. Dul'keit leg.; 1 male, $200 \mathrm{~km}$ E of Magadan (Yamsk), 29.VIII.1964 L. Ivliev leg.; 2 males, 4 females, Magadan ("Garden of Museum"), 1. IX. 1963 Vas'kovskii leg.; 4 males, 2 females, Magadan (Kamenushka) 15, 17, 28.IX.1963 D. Kononov leg.; 4 females, Magadan (Nagaevo) 10.IX.1963 D. Kononov leg. (IBSS).

Description. Length of the forewing 15-21 $\mathrm{mm}$. The Kamchatian specimens are closely related to the East Siberian subspecies tunkunata (Bang-Haas, 1910) and the Sakhalinian-Japanese subspecies autumnus (Bryk, 1942), by characters of the male and female genitalia. These are: uncus bottle-like, drawn to the apex, anterior process of saccus wide basally; corpus bursae with almost cylindrical sclerotized neck without membranous dilation on its left side. However, the Kamchatian specimens differ clearly from the related subspecies in the wing marking. Despite the variation in colouration of the wings from light to relatively dark, all of them have transverse lines indistinct and weakly visible against the ground colour. Only the double whitish postmedial transverse line on the forewing is more or less distinct. The females are coloured the same as the males. The specimens from the North Okhotian coast (Magadan and Zavyalova Island) are similar to the Kamchatian ones, but on average smaller in size.

Etymology. The subspecies is named after $\mathrm{Mr}$. A. N. Smetanin, the naturalist and amateur entomologist from Petropavlovsk-Kamchatskii.

Additional localities. Shiveluch volcano, Zhupanovo, Elisovo, Pogranichnyi, Sosnovka, Petropavlovsk-Kamchatskii, Tarja, AchomtenBay.

Distribution. Subspecies smetanini: north of the Far East (south of Magadansk Province, Kamchatka Peninsula). The other subspecies: Europe, Caucasus, Transcaucasia, Siberia (excluding North), south of the Far East (Amursk Province, south of Khabarovsk Territory, Primorsk Territory, Sakhalin Island, South Kuril Islands), North Mongolia, Japan, North America (Newfoundland and Labrador, south to British Columbia, Pennsylvania).

Biology. In the Kamchatka Peninsula the species is common and widely inhabits Betula, Alnus and Salix forests in the lowlands and submontane zones. Betula ermanii, Betula platyphilla, Alnus hirsuta and Salix sachalinensis are reported as food plants for larvae of the species in the Peninsula (Lobkova, 1986, Smetanin, 1989).

\section{Operophtera peninsularis Djakonov, 1931}

Operophtera (Rachela) peninsularis: Djakonov 1931: 391, figures 1-7; Prout 1936: 95.

Operophthera [misspelling] peninsularis: Kurentzov 1963: 21, 33, 52; Kurentzov 1966: 66, 72; Ivliev 1966: 84; Viidalepp 1977: 564; Beljaev 1988: 137; Beljaev 1995: 150. Operoptera [misspelling] peninsularis: Sedykh 1979: 292. Operophtera peninsularis: Lobkova 1986: 108; Viidalepp 1996: 27.

Material examined. 12 males, Kichiga River, 830.IX.1986 A. Smetanin leg.; 1 male, Kronotskii Cape, 17.VIII.1986 L. Lobkova leg.

Additional localities. Palana, Zhupanovo, Pogranichnyi, Petropavlovsk-Kamchatskii, Tarja.

Distribution. Far East (nominotypical subspecies: south of Magadansk Province, Kamchatka Peninsula; the other subspecies: Sakhalin Island).

Biology. In the Kamchatka Peninsula the species is common and widely inhabits the Betula, Alnus and Salix forests in the lowlands and submontane zones. Betula ermanii, Alnus hirsuta, Alnus kamtschatica, Salix sp. and Ribes sp. are reported as food plants for larvae of the species in the Peninsula (Lobkova 1986, Beljaev 1988, 1995).

Remarks. Specimens from Sakhalin Island are larger than the Kamchatian and Magadanian ones and have some differences in the shape of the transverse lines of the wings. To separate subspecies they probably they need to be erected.

\section{Psychophora sabini (Kirby, 1824)}

Cidaria (Psychophora) frigidaria (Guenée, 1858): Djakonov 1931: 403.

Cidaria frigidaria: Kurentzov 1963: 23, 25; Kurentzov 1966: 69; Sedykh 1979: 293.

Psychophora sabinii (Curtis, 1835) [incorrect authorship of the invalid emendation]: Viidalepp 1977: 568.

Psychophora sabini sabini: Viidalepp 1996: 15.

Material examined. Paramushir Island: 1 male, Ebeko volcano (on rocks), 4.VIII.1964 N. Azarova leg.

Additional localities. Klyuchevskaya Sopka volcano, Kikhpinych volcano. 
Distribution. Arctic Europe, Novaya Zemlya Island, north of the Far East (Magadansk Province, Chukotka, Kamchatka Peninsula, North Kuril Islands - first record), Arctic America, Greenland.

Biology. In the Kamchatka Peninsula the species is known only from the several specimens collected in the alpine belt.

Remarks. The single examined specimen from Paramushir Island is slightly different from the Chukotian ones on its facies and genitalia. Viidalepp (1996) refers the Kamchatian Psychophora sabini to the American nominotypical subspecies, and the Chukotian one to the North European subspecies frigidaria. This is biogeographically astonishing. The taxonomic position of the Kamchatian Psychophora sabini needs to be revised.

\section{Martania taeniatum obsoletum (Djakonov, 1929)}

Cidaria taeniata (Stephens, 1831) aberration? an varietas?: Alpheraky 1897: 342;

Larentia taeniata: Staudinger \& Rebel 1901: 294. Cidaria (Perizoma) taeniata: Djakonov 1929: 13; Djakonov 1931: 406.

Cidaria taeniata: Djakonov 1929: 22.

Cidaria (Perizoma) taeniata obsoleta Djakonov 1929:

13; Djakonov 1931: 406; Prout 1938: 163.

Cidaria taeniata obsoleta: Djakonov 1929: 22.

Perizoma taeniata obsoleta: Viidalepp 1977: 572. Cidaria taeniata Thunberg [incorrect authorship]: Sedykh 1979: 293.

Perizoma taeniatum obsoletum: Viidalepp 1996: 33. Martania taeniata: Mironov 2000: 119.

Material examined. 12 males, 10 females: Barmotina River, Zhupanovo, "Khutor, MTS" (Razdol'nyi), Nachiki, Maloe Nachikinskoe Lake, Elisovo, Ust'-Bol'sheretsk, Bol'sheretsk, from 15.VII. to 24. VIII.

Additional localities. Esso, Shchapino, Mil'kovo, Shumnaya River, PetropavlovskKamchatskii, Tarja.

Distribution. Subspecies obsoletum: east of the Far East (Kamchatka Peninsula). The other subspecies: North, Central and East Europe, Urals, mountains of South Siberia, Transbaikalia, Far East (Amursk Province, south of Khabarovsk Territory, Primorsk Territory, Sakhalin Island), Korea, Japan.
Biology. The species widely inhabits Betula forests in the lowlands and submontane zones.

Remarks. Djakonov (1931) noted that the albinistic form obsoletum occurs along the east coast of the Kamchatka Peninsula, whereas the dark form, which is similar to the nominotypical form in having a blackish medial area on the forewing), occurs in the central part of the Peninsula. However, based on the examined material, both dark and albinistic forms occur together in both localities. The dark form has a very light terminal area on the forewing, as in typical obsoletum, and on the basis of that we consider the dark form to belong to the subspecies obsoletum. The male and female genitalia of Martania taeniatum obsoletum are not markedly different from those of Martania taeniatum from the Amur basin and the Sakhalin Island, which is coloured similar to European representatives.

\section{Perizoma haasi (Hedemann, 1881)}

Cidaria haasi: Sedykh 1979: 293. Perizoma haasi: Viidalepp 1996: 34.

Localities. Zhupanovo.

Distribution. Far East (Kamchatka Peninsula, Amursk Province, north of the Primorsk Territory, South Kuril Islands), Japan (Honshu, S. Alps).

Remarks. The single specimen reported from the Kamchatka Peninsula (Sedykh 1979) was not examined, but there are no reasons for excluding this species from the Kamchatian fauna.

\section{Gagitodes sagittatus albiflua (Prout, 1938)}

Perizoma sagittatum (Fabricius, 1787): Beljaev \& Kuranishi 2000: 240 .

Material examined. 1 female, Nachiki, 1.VIII.1958 A. Kurentzov, L. Ivliev \& D. Kononov leg.; 4 male, $17 \mathrm{~km}$ NE of Malki (Poperechnaya River), 27, 28.VII.1997 R. B. Kuranishi \& Yu. Tshistjakov leg.

Distribution. Subspecies albiflua: southeast of Siberia (Transbaikalia), Far East (Kamchatka Peninsula, south of Khabarovsk Territory, 
Primorsk Territory, Sakhalin Island, South Kuril Islands), Mongolia, Korea, Japan. The other subspecies: Europe, China.

Biology. The examined specimens were collected in Betula forests.

Remarks. The Kamchatian specimens are slightly paler than the continental ones, but, based on their wing pattern, they clearly belong to the subspecies albiflua.

\section{Eupithecia zibellinata Christoph, 1881}

Eupithecia zibellinata: Djakonov 1929: 15; Djakonov 1931: 407; Kurentzov 1963: 22, 38, 52; Sedykh 1979: 293; Viidalepp \& Mironov 1988a: 202; Mironov 1990: 661; Viidalepp 1996: 35.

Eupithecia caliginea zibellinata: Prout 1938: 187; Viidalepp 1978: 756.

Material examined. 1 female, Mil'kovo, 20.VI.1958 A. Kurentzov, L. Ivliev \& D. Kononov leg.; 1 female, Bol'sheretsk, 5.VIII.1992 O. Kosterin leg.

Additional localities. Klutchi, Zhupanovo.

Distribution. Far East (Kamchatka Peninsula, Amursk Province, south of Khabarovsk Territory, Primorsk Territory, Sakhalin Island).

\section{Eupithecia bohatschi Staudinger, 1897}

Eupithecia bohatschi: Djakonov, 1929: 18; Djakonov, 1931: 407; Prout, 1938: 194; Kurentzov, 1966: 66; Sedykh, 1979: 293; Viidalepp \& Mironov, 1988a: 202; Mironov, 1990: 661; Viidalepp, 1996: 35.

Material examined. 2 males, 1 female: Shchapino, 2.VII.1958, Laso, 18.VII.1958 A. Kurentzov, L. Ivliev \& D. Kononov leg.

Additional localities. Klyuchi, Kosyrevsk, Zhupanovo, Elisovo, Pogranichnyi, Petropavlovsk-Kamchatskii.

Distribution. South Siberia (Tuva, Transbaikalia), Far East (Kamchatka Peninsula, Amursk Province, south of Khabarovsk Territory, Primorsk Territory, Sakhalin Island), Mongolia, North China, Korea.

Biology. In the Kamchatka Peninsula the species widely inhabits the Betula and Larix forests in the lowlands and submontane zones.

\section{Eupithecia abietaria debrunneata Staudinger, 1897}

Eupithecia abietaria (Goeze, 1781): Kurentzov \& Ivliev 1960: 98, 102, figure 2; Ivliev \& Kononov 1962: 86, figure 7; Ivliev 1963: 72; Kurentzov 1963: 17, 23, 39, figure 6; Kurentzov, 1966: 65, 66; Ivliev 1966: 80, 86; Sedykh 1979: 293.

Eupithecia abietaria debrunneata: Viidalepp \& Mironov 1988a: 200; Mironov 1990: 662; Viidalepp 1996: 35.

Material examined. 1 male, 1 female, Nachiki (Nachikinskoe Zerkal'tse Mt.), 31.VII, 3.VIII.1958 A. Kurentzov, L. Ivliev \& D. Kononov leg.; 1 male, 1 female, "Kamchatka", VIII.1958, larva on Pinus pumila, ex pupa 25.VII.1959 L. Ivliev leg.

Additional localities. Kurentzov \& Ivliev (1960) cite this species as widely distibuted in Elisovskii, Ust'-Bol'sheretskii, Mil'kovskii and Ust'-Kamchatskii Districts, in the southern, central, eastern and western parts of the Kamchatka Peninsula.

Distribution. Subspecies debrunneata: West Siberia, South Siberia (Altai, Sayan Mts, Transbaikalia), Far East (Kamchatka Peninsula, Amursk Province, south of Khabarovsk Territory, Primorsk Territory, Sakhalin Island, South Kuril Islands), Japan. The other subspecies: North, Central and East Europe, Caucasus, Transcaucasia, Urals.

Biology. Kurentzov and Ivliev (Kurentzov \& Ivliev 1960, Ivliev \& Kononov 1962, Ivliev 1963, 1966, Kurentzov 1963, 1966) note this species as a mass pest of cones of Pinus pumila in the alpine and subalpine belts.

\section{Eupithecia pygmaeata (Hübner, 1799)}

Eupithecia pygmaeata: Viidalepp \& Mironov 1988a: 205; Mironov 1990: 663; Viidalepp 1996: 36.

Localities. Kosyrevsk.

Distribution. North, Central and East Europe, West Siberia, South Siberia, Yakutia, Far East (Magadansk Province, Kamchatka Peninsula, Primorsk Territory, Sakhalin Island), North Mongolia, North America (Alaska to Newfoundland, south to Gaspé Peninsula, Quebec and Colorado). 
Eupithecia pusillata (Denis \& Schiffermüller, 1775)

Eupithecia sobrinata (Hübner, 1817): Djakonov 1929: 18; Djakonov 1931: 408; Sedykh 1979: 293; Viidalepp 1978: 756.

Eupithecia pusillata: Viidalepp \& Mironov 1988a: 212; Mironov 1990: 665. Viidalepp 1996: 37.

Material examined. 1 female, PetropavlovskKamchatskii (Airport), 23.VIII.1960 A. Kurentzov \& D. Kononov leg.; 1 female, Paratunka, 21.VII.1976 V. Kirpichnikova leg.

Additional localities. Kosyrevsk, Shchapino, Mil'kovo, Zhupanovo, Elisovo.

Distribution. Europe, Caucasus, Transcaucasia, Urals, West Siberia, Altai, Transbaikalia, Yakutia, Far East (Kamchatka Peninsula, Sakhalin Island), North America, Greenland.

\section{Eupithecia virgaureata Doubleday, 1861}

Eupithecia virgaureata: Djakonov 1929: 18; Djakonov 1931: 408; Sedykh 1979: 293; Viidalepp \& Mironov 1988b: 292; Mironov 1990: 665: Viidalepp 1996: 37.

Eupithecia pimpinellata (Hübner, 1813): Djakonov 1929: 18; Djakonov 1931: 408; Prout 1938: 200 [misidentification]

Eupithecia pimpinellata (Hübner, 1813): Sedykh 1979: 293 [misidentification?]

Material examined. 1 male, labelled as follows: "Kamtschatka, Malaise", "906", "microsc. praep. N 635. Male. "; "Eupithecia pimpenellata $\mathrm{H}$. S., Djakonov det. "; "5796 E94 +" (NHR).

Localities. Klyuchi, Kosyrevsk, Esso?, Mil'kovo, Elisovo, Uson volcano, Zhupanovo, Petropavlovsk-Kamchatskii.

Distribution. Europe, Caucasus, Transcaucasia, West Siberia, South Siberia (Altai), Far East (Kamchatka Peninsula, Amursk Province, Primorsk Territory, Sakhalin Island), Mongolia, Japan.

\section{Eupithecia lariciata (Freyer, 1841)}

Eupithecia lariciata: Viidalepp \& Mironov 1988a: 209; Mironov 1990: 666; Viidalepp 1996: 37; Beljaev \& Kuranishi 2000: 240.
Material examined. 68 males, 75 females: $15 \mathrm{~km}$ NE of Esso (Pravaya Kamchatka River), $17 \mathrm{~km}$ NE of Malki (Poperechnaya River), $20 \mathrm{~km} \mathrm{~S}$ of Pushchino (Pravaya Kamchatka River), from 6. VII. to 12.VII.1996 R. B. Kuranishi leg. \& Yu. Tshistjakov leg.

Additional localities. Kosyrevsk, PetropavlovskKamchatskii.

Distribution. Europe, Urals, West Siberia, West and Central Siberia, Altai, Transbaikalia, Yakutia, Far East (Kamchatka Peninsula, Amursk Province, south of Khabarovsk Territory, Primorsk Territory, Sakhalin Island), Mongolia, Korea, Japan, North America (Yukon to Newfoundland, south to New York and Arizona).

Biology. Until the Japanese-Russian expeditions (1996-1997) the E. lariciata (Freyer) was known in the Kamchatka Peninsula from a few specimens only. Evidently an outbreak of this Larix pest had taken place in 1996.

\section{Eupithecia actaeata praenubilata Inoue, 1958}

Eupithecia actaeata Walderdorff, 1869: Djakonov 1929: 15; Djakonov 1931: 407; Prout 1938: 191; Kurentzov 1963: 22, 38; Sedykh 1979: 293; Viidalepp \& Mironov 1988a: 208.

Eupithecia actaeata praenubilata: Mironov 1990: 667; Viidalepp 1996: 37.

Material examined. 1 male, Ust'-Bol'sheretsk, 16.VII.1976 V. Kirpichnikova leg.;1 female, Bol'sheretsk, 6.VIII.1992 O. Kosterin leg.

Additional localities. Klyuchi, PetropavlovskKamchatskii.

Distribution. Subspecies praenubilata: Urals, Altai, South Siberia (Sayan Mts, Baikal region, Transbaikalia), Far East (Kamchatka Peninsula, south of Khabarovsk Territory, Primorsk Territory, Sakhalin Island, South Kuril Islands), Japan. The other subspecies: Europe.

\section{Eupithecia homogrammata kamtschatica Viidalepp \& Mironov, 1988}

Tephroclystia ?indigata (Hübner, 1813): Staudinger \& Rebel 1901: 310 [misidentification] 
Eupithecia homogrammata Dietze, 1908: Djakonov 1929: 15; Djakonov 1931: 407; Prout 1938: 183; Kurentzov 1963: 38; Viidalepp 1978: 752; Sedykh 1979: 293; Beljaev \& Kuranishi 2000: 240.

Eupithecia homogrammata kamtschatica Viidalepp \& Mironov 1988a: 203, 214; Mironov 1990: 668; Viidalepp 1996: 39.

Material examined. 15 males, 6 females, Azhabach'e Lake (Bushuika River), $15 \mathrm{~km} \mathrm{NE}$ of Esso (Pravaya Kamchatka River), Mil'kovo, Zhupanovo, Nachiki (Nachikinskoe Lake), Ust'Bol'sheretsk, Paratunka, from 21.VI. to 5.VIII.

Additional localities. Klyuchi, Nerpich'e Lake, Kosyrevsk, Geisernaya River, Malki, Koryaki, Elisovo, Petropavlovsk-Kamchatskii, Ozernovskii.

Distribution. Subspecies kamtschatica: east of the Far East (Kamchatka Peninsula). The other subspecies: South of the Far East (Amursk Province, south of Khabarovsk Territory, Primorsk Territory, Sakhalin Island, South Kuril Islands), China, Korea, Japan.

Biology. In the Kamchatka Peninsula the species widely inhabits the Betula forests in the lowlands and submontane zones.

Remarks. The Kamchatian subspecies is distinguished by the much paler coloraution of its wings. The subspecies is somewhat similar to Eupithecia indigata on its facies, and it was evidently confused with the latter by Staudinger \& Rebel (1901).

\section{Eupithecia gelidata hyperboreata Staudinger, 1861}

Eupithecia gelidata Möschler, 1860: Beljaev \& Kuranishi 2000: 240.

Material examined. 1 female, Ust'-Bol'sheretsk, 16.VII.1976 V. Kirpichnikova leg.; 1 male, Shelekhov Bay, 17.VII.1997 E. Makarchenko \& S. Kholin leg. North Koryakiya: 1 male, Dezhneva Bay, 12.VII.1991 I. Lyubechanskii leg.

Distribution. Subspecies hyperboreata: North, Central and East (excepting its southern part) Europe, Polar Urals, South Siberia (Altai, Tuva, Baikal region), north of the Far East (Magadansk Province, North Koryakiya — first record, Kam- chatka Peninsula - first record, North Kuril Islands), Greenland. The other subspecies: North America (Alaska to Newfoundland, south to New England and New Mexico).

\section{Eupithecia pseudosatyrata Djakonov, 1929}

Eupithecia pseudosatyrata: Djakonov 1929: 16, figure 2, plate 2, figures 4-5; Djakonov 1931: 407; Prout 1938: 193; Viidalepp 1978: 754; Sedykh 1979: 293; Viidalepp \& Mironov 1988b: 287; Mironov 1991: 163; Viidalepp 1996: 42; Beljaev \& Kuranishi 2000: 240.

Material examined. 10 males, 6 females: Azhabach'e Lake (Bushuika River), $15 \mathrm{~km}$ NE of Esso (Pravaya Kamchatka River), Mil'kovo, Shchapino, $17 \mathrm{~km}$ NE of Malki (Poperechnaya River), Nachiki (Nachikinskoe Lake), Ust'Bol'sheretsk, Bol'sheretsk, from 20.VI. to 6.VIII. Additional localities. Klyuchi, Nerpich'e Lake, Petropavlovsk-Kamchatskii.

Distribution. East of the Far East (Kamchatka Peninsula).

Biology. In the Kamchatka Peninsula the species widely inhabits the Betula, Alnus and Larix forests in the lowlands and submontane zones.

\section{Eupithecia antaggregata Inoue, 1977.}

Material examined. 1 female, Middle Kavyicha River, 25.VI.1968 O. Kazantsev leg.

Distribution. South of West Siberia, Altai, Transbaikalia, Far East (Kamchatka Peninsula first record, Amursk Province, south of Khabarovsk Territory, Primorsk Territory, South Kuril Islands), Mongolia, Japan.

Remarks. The single female examined is slightly smaller than those from South Siberia and the south of the Far East; it has more distinct transverse lines on the wings and finer spines in the corpus bursae.

\section{Eupithecia lvovskyi Mironov, 1988}

Eupithecialvovskyi Mironov, 1988 in Viidalepp \& Mironov 1988b: 285, 293, figure 3g-e; Mironov 1991: 164. Viidalepp 1996: 43. 


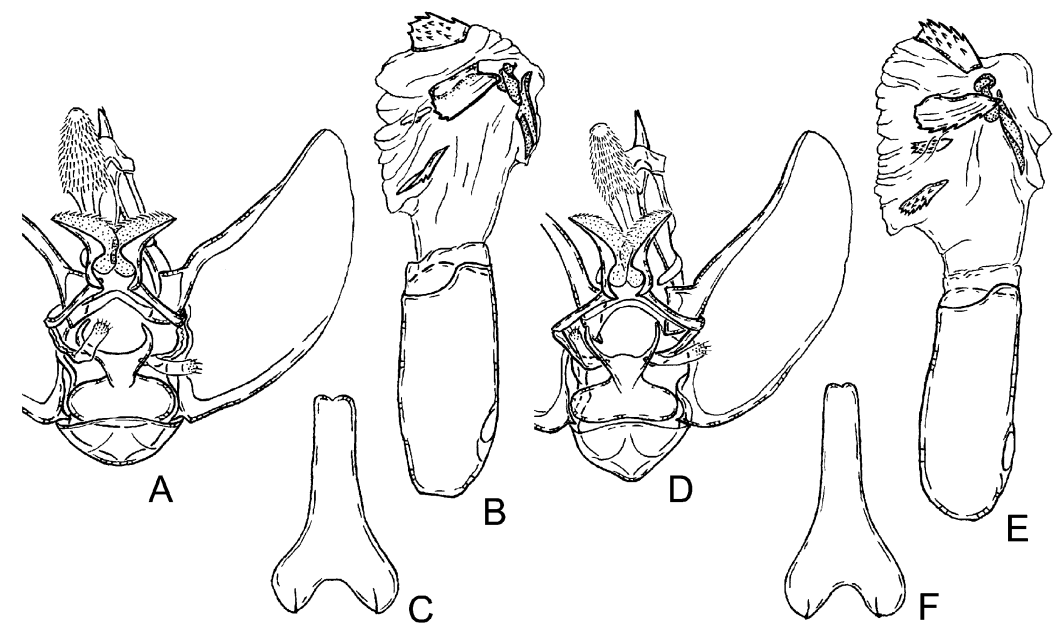

Fig. 8. - a-c. Eupithecia kurilensis mironoviBeljaev, ssp. n., male (paratype). - d-f. Eupithecia kurilensis kurilensis Bryk, Sakhalin Island, male. a, b, d, e male genitalia $(a, d-$ ventral view [left valva not figured] and $b$, e aedeagus) and $c, f-$ VII sternite of abdomen.
Localities. Kosyrevsk.

Distribution. East of the Far East (Kamchatka Peninsula).

Remarks. The species is known from a single specimen only.

Eupithecia kurilensis mironovi Beljaev, ssp. n. (Figs. 5h, 8a-c)

Eupithecia absinthiata (Clerck, 1759): Djakonov 1929: 17; Djakonov 1931: 407; Sedykh 1979: 293 [misidentification] Eupithecia castigata (Hübner, 1813): Konovalova 1970: 175; Sedykh 1979: 293 [misidentification] Eupithecia kurilensis Bryk, 1942: Viidalepp 1978: 754; Viidalepp \& Mironov 1988b: 284; Mironov 1991: 164; Vasilenko 1992: 285; Viidalepp 1996: 43; Beljaev \& Kuranishi 2000: 241.

Eupithecia latipennis Hulst, 1898: Viidalepp 1978: 754 [misidentification]

Eupithecia ussuriensis Dietze, 1910: Mironov 1991: 166; Viidalepp 1996: 44 [misidentification]

Type locality. Russia, Kamchatka Peninsula, Poperechnaya River, 17 km NE of Malki.

Material examined. Holotype. Male, Russia, Kamchatka Peninsula, $17 \mathrm{~km}$ NE of Malki (Poperechnaya River), 27.VII.1997 Yu. Tshistjakov leg. (IBSS). Paratypes. Kamchatka Peninsula: 1 female, Klyuchi, 21.VII.1958 A. Kurentzov, L. Ivliev \& D. Kononov leg.; 2 males, Paratunka, 9, 21.VII.1976 V. Kirpichnikova leg.; 2 males, 2 females, $17 \mathrm{~km}$ NE of Malki (Poperechnaya River), 5.VII.1996, 27, 28.VII.1997 R. B. Kuranishi leg.; 3 males, 17 km NE of Malki
(Poperechnaya River), 5.VII.1996, Azhabach'e Lake (Bushuika River), 13.VII.1996 Yu. Tshistjakov leg. Paramushir Island: 1 female, Shelekhov Bay, 11.VIII.1964 G. Krivolutzkaja leg., labelled as "Eupithecia castigata Hübner"; ditto, 11.VIII.1964 N. Azarova, Z. Konovalova, G. Krivolutzkaja \& A. Kupyanskaya leg.; 8 males, 1 female, ditto, 17.VII.1997 R. B. Kuranishi leg.; 2 females, Vasilyev Peninsula, 3.VIII.1996 A. Lelei leg. Additional material. Kamchatka Peninsula: 1 male labelled as follows: "Kamtschatka, Malaise"; "microsc. praep. N 637. Male."; "Eupithecia absinthiata Cl. m, Djakonov det."; "5329 E94 +" (NHR). 1male labelled as follows: "Kamtschatka, Malaise"; "microsc. praep. N 638. Female."; "Eupithecia absinthiata $\mathrm{Cl}$. m, Djakonov det."; "5338 E94 +" (NHR). Both of the mentioned microscopic preparations are missing.

Description. The Kamchatian and North Kurilian specimens of the subspecies mironovi have darker or more contrasting wing markings, and they are markedly large (forewing of 12-14 $\mathrm{mm}$ in length), in comparison with the nominotypical subspecies of Eupithecia kurilensis from Sakhalin and Hokkaido (forewing 11-12 mm in length). In the male genitalia, mironovi is clearly distinguishable from Eupithecia kurilensis kurilensis (Fig. 8d-f) in having a wider valva, and in the cornuti: pair of proximal small toothed plates markedly smaller, with a few teeth only, the largest plate almost quadrangular, without teeth on its lateral sides and with a few small ones on its 
rib. In the female genitalia, the newly described subspecies differs in the somewhat smaller size of the corpus bursae and thinner spines on its inner side.

Etymology. The subspecies is named after Dr. V. G. Mironov, noted specialist in geometrid moths of the tribe Eupitheciini.

Additional localities. Shumnaya River?, Kikhpinych volcano, Geisernaya River, Zhupanovo, Elisovo, Pogranichnyi, Sosnovka, PetropavlovskKamchatskii, Severo-Kuril'sk.

Distribution. Subspecies mironovi: east of the Far East (Kamchatka Peninsula, North Kuril Islands). The other subspecies: Southeast of the Far East (Sakhalin Island, South Kuril Islands), Japan (Hokkaido).

Remarks. Among the specimens of the Eupithecia kurilensis kept in the IBSS, one of the individuals collected on Paramushir Island in 1964 has a label "Eupithecia castigata Hübner" written by Konovalova. Undoubtedly, based on this determination, Konovalova (1970) cited the occurrence of the latter species in the North Kuril Islands. Evidently, Sedykh (1979) confused Eupithecia kurilensis with Eupithecia castigata too. Apparently, subsequent notes from the Kamchatka Peninsula of Eupithecia latipennis and Eupithecia ussuriensis (Viidalepp 1978, 1996, Mironov, 1991), treated by different authors as species closely related to Eupithecia subfuscata (Haworth, 1809) (=Eupithecia castigata) or it synonyms, are based on the references by Konovalova and Sedykh. The examination of the specimens from NHR, studied by Djakonov, shows that records of $E$. absinthiata from the Kamchatka Peninsula (Djakonov 1929, 1931) are misidentifications of E. kurilensis. Probably, Sedykh (1979) confused these species too.

\section{Eupithecia veratraria geiserata Mironov, 1988}

Eupithecia veratraria Herrich-Schäffer, 1848: Djakonov 1929: 17; Djakonov 1931: 407; Beljaev \& Kuranishi 2000: 241.

Eupithecia vertraria [misspelling]: Sedykh 1979: 293. Eupithecia veratraria geiserata Mironov in Viidalepp \& Mironov 1988b: 285, 293, figure 3a-b; Mironov 1991: 164; Viidalepp 1996: 43.

Material examined. 2 males, 4 females:
Azhabach'e Lake (Bushuika River), 17 km NE of Malki (Poperechnaya River), Ust'-Bol'sheretsk, Bol'sheretsk, from 13.VII. to 6.VIII.

Additional localities. Zhupanovo, Petropavlovsk-Kamchatskii.

Distribution. Subspecies geiserata: east of the Far East (Kamchatka Peninsula). The other subspecies: Central and South Europe (mountains), northern Fennoscandia, Polar Urals, South Siberia (Altai, Transbaikalia), northwest and south of the Far East (Magadansk Province, south of Khabarovsk Territory, Primorsk Territory), Japan (Honshu, mountains).

\section{Eupithecia succenturiata exalbidata Staudinger, 1901}

Eupithecia succenturiata exalbidata: Djakonov 1929: 18; Djakonov 1931: 408; Prout 1938: 195; Viidalepp 1978: 754; Mironov 1991: 166; Viidalepp 1996: 45.

Eupithecia succenturiata exallidata [misspelling]: Sedykh 1979: 293.

Eupithecia succenturiata (Linnaeus, 1758): Viidalepp \& Mironov 1988b: 291; Beljaev \& Kuranishi 2000: 241.

Material examined. 14 males, 11 females: Shchapino, 31 km NE of Malki, Nachiki, Nachikinskoe Lake, Paratunka, Pauzhetka, Shumshu Island (Kosyrevskoe), Severo-Kuril'sk, Shelekhov Bay, from 6.VII. to 1.VIII.

Additional localities. Klutshi, Nerpich'e Lake, Kosyrevsk, Ust'-Sopochnoe, Ichinskii, Pushchino, Geisernaya River, Zhupanovo, Elisovo, Petropavlovsk-Kamchatskii.

Distribution. Subspecies exalbidata: East Kazakhstan, east of Middle Asia, Nortwest China, West and Central Siberia, Altai, Transbaikalia, Yakutia, east of the Far East (Kamchatka Peninsula, North Kuril Islands). The other subspecies: Europe, Asia Minor, Caucasus, Transcaucasia, Urals.

Remarks. Viidalepp \& Mironov (1988b) supposed a human introduction of Eupithecia succenturiata to the Kamchatka Peninsula. However, the high polymorphism of the examined specimens, accompanied with the development of very light-coloured forms, similar to those of many other Kamchatian geometrid moths, suggests a long-term existence of this species in the Peninsula. 


\section{Carsia sororiata (Hübner 1813)}

Carsia paludata (Thunberg, 1788): Djakonov 1929: 5; Djakonov 1931: 391; Kurentzov 1963: 25, 27, 43, 51; Kurentzov 1966: 65, 69; Sedykh 1979: 292.

Carsia sororiata: Viidalepp 1978: 758; Viidalepp 1996: 46.

Material examined. 22 males, 42 females: Karaga River, Elovka River ("Lespromkhoz"), Nachiki (Bezymyannoe Lake), Maloe Nachikinskoe Lake, from 25.VII. to 16.VIII. North Koryakiya: 1 male, 2 females, Tilichiki, 20.VIII.1959 A. Kurentzov, L. Ivliev \& D. Kononov leg.; 1 male, 2 females, Kamenskoe, 7, 10.VIII.1960 L. Ivliev leg.

Additional localities. Mashura, Esso, Aga Mt., Uson volcano. Kurentzov (1963) noted this pecies from south-west of the Kamchatka Peninsula (Ust'-Bol'sheretskii District) without specific locality.

Distribution. North, Northeast and Central Europe, Urals, Siberia, Far East (Magadansk Province, North Koryakiya - first record, Kamchatka Peninsula, Amursk Province, Khabarovsk Territory, mountains of Primorsk Territory, Sakhalin Island), North Mongolia, North America (Alaska to Newfoundland, south to New Hampshire).

Biology. In the Kamchatka Peninsula the species prefers marshes, tundra and crowberry brakes in the lowlands, and alpine meadow with mountain tundra up to $1200 \mathrm{~m}$ above sea level.

Remarks. The Kamchatian specimens are similar to those from East Siberia, and some specimens from North Europe, in dark ground colour of the wings with pink hue on the forewing.

\section{Polythrena coloraria pallida Djakonov, 1929}

Polythrena coloraria pallida: Djakonov 1929: 4; Djakonov 1931: 390; Prout 1937: 82; Viidalepp 1977: 572; Sedykh 1979: 292; Viidalepp 1996: 26.

Polythrena coloraria (Herrich-Schäffer, 1855): Kurentzov 1963: 20, 28.

Material examined. 1 male, Klyuchi, 22.VII.1958 A. Kurentzov, L. Ivliev \& D. Kononov leg.; 1 male, Klyuchi, 21.VI.1975 L. Lobkova leg. 1 female, Shchapino, larva on Ribes sp., 24.VIII.1960, imago ex pupa 7.IV.1961 V. Minchenko leg.

Additional localities. Kosyrevsk, Zhupanovo.

Distribution. Subspecies pallida: southeast of Siberia (Baikal region, Transbaicalia), Northeast
Siberia, east of the Far East (Kamchatka Peninsula). The other subspecies: Northeast Europe, North Urals, mountains of South Siberia (Altai, Sayan Mts), Yakutia, Korea (mountains).

Biology. In the Kamchatka Peninsula the species is rarely collected in submontane zones. Ribes $\mathrm{sp}$. is a food plant for its larvae in the Peninsula, based on the labels on hatched specimens in IBSS collection.

Remarks. The examined specimens are quite similar to the nominotypical form in the wing pattern, and differ only in slightly paler ground colour of the wings. Their subspecific rank is doubtful. Distribution of the subspecies is given following Viidalepp (1996).

\section{Venusia cambrica Curtis, 1839}

Venusia cambrica: Djakonov 1929: 15; Djakonov 1931: 406; Kurentzov 1963: 38; Konovalova 1970: 174; Viidalepp 1977: 564; Viidalepp 1996: 29; Beljaev \& Kuranishi 2000: 241.

Venusia gambrica [misspelling]: Sedykh 1979: 293.

Material examined. 189 males, 55 females: Azhabach'e Lake (Bushuika River), $15 \mathrm{~km}$ NE of Esso (Pravaya Kamchatka River), $20 \mathrm{~km} \mathrm{~S}$ of Pushchino (Pravaya Kamchatka River), Zhupanovo, $10 \mathrm{~km}$ N of Gannaly, $17 \mathrm{~km} \mathrm{NE}$ of Malki (Poperechnaya River), "Khutor, MTS" [Razdol'nyi], Nachiki, Nachikinskoe Lake, Nachikinskoe Zerkal'tse Mt., Elisovo, Petropavlovsk-Kamchatskii, Paratunka, Pauzhetka, Shumshu Island, Severo-Kuril'sk, Ebeko volcano, Shelekhov Bay, Shelekhovka River, Ban'chzhou, from 5.VII. to 23.VIII.

Additional localities. Ust'-Sopochnoe, Ichinskii, Shumnaya River, Geisernaya River, Pogranichnyi.

Distribution. North, Central and East Europe, Turkey, Urals, West and Central Siberia, Altai, Transbaikalia, Far East (Kamchatka Peninsula, Amursk Province, south of Khabarovsk Territory, Primorsk Territory, Sakhalin Island, Kuril Islands), Korea, Japan, North America (Alaska to Newfoundland, south to North California and Massachusetts).

Biology. In the Kamchatka Peninsula and on the North Kuril Islands the species is very common in the lowland and submontane zones. 
Remarks. The Kamchatian specimens differ from those found south of the Far East and in Japan, in having transverse lines of the wings greyish, almost without brownish hue, and in having finer black marking with reduced pair of black strokes near the base of veins $\mathrm{M}_{3}$ and $\mathrm{Cu}_{1}$ on the forewing. However, they are similar to the Far Eastern and Japanese ones in having the forewing postmedial transverse line less inclined to the base of wing than that of European Venusia cambrica.

\section{Hydrelia flammeolaria (Hufnagel, 1767)}

Hydrelia flammeolaria: Djakonov 1929: 15; Djakonov 1931: 406; Sedykh 1979: 293; Viidalepp 1996: 29.

Material examined. 80 males, 10 females: Klyuchi, Nikolka Mt. (Golets), Laso, 40 km NE of Mil'kivo (Kirganik River, "Bichki”), Middle Kavyicha River, "Khutor, MTS” (Razdol'nyi), Nachiki, Nachikinskoe Lake,Elisovo, Pauzhetka, from 25.VI. to 11.VIII.

Additional localities. Zhupanovo, Petropavlovsk-Kamchatskii.

Distribution. Europe, Caucasus, Transcaucasia, Urals, Siberia (except extreme north), Far East (Kamchatka Peninsula, Amursk Province, south of Khabarovsk Territory, Primorsk Territory, Sakhalin Island, South Kuril Islands), Korea, Japan.

Biology. In the Kamchatka Peninsula the species inhabits various types of vegetation from the lowlands to alpine belt up to $1400 \mathrm{~m}$ above sea level.

Remarks. The Kamchatian specimens are on average smaller than those from the south of the Far East.

Trichopteryx polycommata grisea (Djakonov, 1926)

Nothopteryx polycommata (Denis \& Schiffermüller, 1775): Djakonov 1931: 391; Sedykh 1979: 292.

Trichopteryx polycommata grisea: Viidalepp 1978: 758; Viidalepp 1996: 49.

Localities. Klyuchi, Zhupanovo, Pogranichnyi.

Distribution. Subspecies grisea: North Urals, South Siberia (Altai, Sayan Mts), northeast of
Kazakhstan, east of the Far East (Kamchatka Peninsula). The other subspecies: Europe, Caucasus, Transcaucasia, south of the Far East (Primorsk Territory), Japan (Hokkaido).

\section{A list of the species of the Geometridae doubtful for the Kamchatka Peninsula and adjacent islands.}

Abraxas grossulariata (Linnaeus, 1758)

Abraxas grossulariata: Semakov 1971: 281.

Remarks. See remarks on Macaria halituaria.

\section{Lomaspilis opis (Butler, 1878)}

Lomaspilis marginata opis (Butler, 1878): Djakonov 1929: 19; Djakonov 1931: 408.

$$
\text { L. opis: Sedykh 1979: } 293 .
$$

Remarks. See remarks on Lomaspilis marginata amurensis.

\section{Macaria wauaria (Linnaeus, 1758)}

Itame wauaria (Linnaeus, 1758): Djakonov 1929: 20; Djakonov 1931: 410; Sedykh 1979: 293; Viidalepp 1996: 75.

Itame wanaria [misspelling]: Semakov 1972: 61.

Remarks. See remarks to Macaria halituaria.

Ascotis selenaria (Denis \& Schiffermüller, 1775)

Boarmia selenaria: Sedykh 1979: 293.

Remarks. The occurrence in the Kamchatka Peninsula of this relatively southern species is doubtful, especially on mountains. Originally Sedykh (1979) noted it from Vachkazhech volcano.

\section{Xanthorhoe spadicearia (Denis \& Schiffer- müller, 1775)}

Cidaria ferrugata spadicearia (Borkhausen, 1794): Alpheraky 1897: 343. 
Cidaria (Xanthorhoe) spadicearia (Denis \& Schiffermüller, 1775): Djakonov 1929: 9; Djakonov 1931: 402. Cidaria spadicearia: Djakonov 1929: 22; Sedykh 1979: 292. Xanthorhoe spadicearia: Viidalepp 1996: 16.

Remarks. See remarks on Xanthorhoe okhotinaria.

\section{Xanthorhoe montanata (Denis \& Schiffer- müller, 1775)}

Xanthorhoe montanata: Viidalepp 1975: 457.

Xanthorhoe montanata lapponica (Staudinger, 1871): Viidalepp 1979b: 94.

Remarks. The species was noted by the above authors to reach the Kamchatka Peninsula, but without reference to any source of data. It has not been recorded subsequently in the Peninsula.

\section{Epirrhoe tristata (Linnaeus, 1758)}

Cidaria tristata: Alpheraky 1897: 345; Konovalova 1970: 174; Sedykh 1979: 293.

Larentia tristata: Staudinger \& Rebel 1901: 304.

Remarks. See remarks on Epirrhoe hastulata reducta.

\section{Epirrhoe alternata (Müller, 1764)}

Cidaria sociata (Borkhausen, 1794): Alpheraky 1897: 343. Larentia sociata: Staudinger \& Rebel 1901: 302. Cidaria (Epirrhoë) alternata (Müller, 1764): Djakonov 1929: 13; Djakonov 1931: 405.

Cidaria alternata: Sedykh 1979: 293.

Epirrhoe alternata: Viidalepp 1977: 569.

Remarks. See remarks on Epirrhoe supergressa.

\section{Entephria polata (Duponchel, 1830)}

Cidaria (Dasyuris) polata (Duponchel, 1830): Djakonov 1931: 403.

Cidaria polata: Sedykh 1979: 293.

Remarks. See remarks on Entephria punctipes.

\section{Lamptopteryx minna (Butler, 1881).}

Larentia suffumata minna: Staudinger \& Rebel 1901: 297.
Remarks. See remarks on Lampropteryx otregiata.

\section{Dysstroma truncata (Hufnagel, 1767).}

Cidaria truncata: Sedykh 1979: 292.

Remarks. See remarks on Dysstroma pseudimmanatum.

\section{Cidaria fulvata (Forster, 1771)}

Cidaria fulvata (Forster, 1771): Sedykh 1979: 292. Cidaria fulvata fulvata: Viidalepp 1996: 23.

Remarks. See remarks on Cidaria luteata.

\section{Cidaria cognata (Thunberg, 1792)}

Cidaria cognata (Thunberg, 1792): Sedykh 1979: 292.

Remarks. See remarks on Heterothera taigana sounkeana.

\section{Hydriomena ruberata (Freyer, 1831)}

Cidaria ruberata: Sedykh 1979: 293.

Remarks. See remarks on Hydriomena furcata.

\section{Perizoma custodiata (Guenée, [1858])}

Hydriomena custodiata: Sedykh 1979: 292.

Remarks. Occurrence of this Nearctic species in the Kamchatka Peninsula is doubtful.

\section{Eupithecia indigata (Hübner, 1813)}

Tephroclystia ?indigata: Staudinger \& Rebel 1901: 310.

Remarks. See remarks on Eupithecia homogrammata kamtschatica.

\section{Eupithecia pimpinellata (Hübner, 1813)}

Eupithecia pimpinellata: Djakonov 1929: 18; Djakonov 1931: 408; Sedykh 1979: 293. 
Remarks. See Eupithecia virgaureata.

\section{Eupithecia subfuscata (Haworth, 1809)}

Eupithecia castigata (Hübner, 1813): Konovalova 1970: 175; Sedykh 1979: 293.

Remarks. See remarks on Eupithecia kurilensis mironovi.

\section{Eupithecia absinthiata (Clerck, 1759)}

Eupithecia absinthiata: Cl. Djakonov 1929: 17; Djakonov 1931: 407; Sedykh 1979: 293.

Remarks. See remarks to Eupithecia kurilensis mironovi.

\section{Eupithecia ussuriensis Dietze, 1910}

Eupithecia latipennis Hulst, 1898: Viidalepp 1978: 754. Eupithecia ussuriensis Dietze, 1913 [incorrect authorship]: Viidalepp \& Mironov 1988b: 291.

Eupithecia ussuriensis: Mironov 1991: 166.

Remarks. See remarks on Eupithecia kurilensis mironovi.

\section{Conclusions}

In his most careful previous review of the Kamchatian Geometridae, Djakonov (1931) listed 61 species for the Peninsula and estimated this number to be "close to the limit". However, 19 further species have been found after Djakonov's paper, and in the present review we list 80 species for the territory. This number is probably close to the real total number of geometrid species in the territory. More species will probably be found in the Peninsula, especially in the poorly investigated mountaineous districts and in western Kamchatka, but we believe that they will barely amount to ten in number.

Acknowledgements. We would like to express our thanks to Dr. A. Lelei, Dr. Yu. Tshistjakov, Dr. E. Makarchenko, Dr. S. Kholin (Institute of Biology and Soil Science, Vladivostok, Russia) and Dr. R. B. Kuranishi (Natural History Museum and Institute, Chiba, Japan) for pro- viding abundant material of geometrid moths collected in the Kamchatka Peninsula and the North Kuril Islands; to Dr. B. Gustafsson (Naturhistoriska Riksmuseet, Stockholm, Sweden), Prof. K. Mikkola (Zoological Museum, University of Helsinki, Helsinki, Finland), Dr. M. Ponomarenko (Institute of Biology and Soil Science, Vladivostok., Russia) for help in receiving type material from Naturhistoriska Riksmuseet; to Mr. P. Sihvonen (University of Helsinki, Helsinki, Finland) for donation of comparative material from North Europe; to Prof. K. Mikkola, Dr. Lauri Kaila (Zoological Museum, University of Helsinki, Helsinki, Finland) and Mrs. Linda M. Pitkin (The Natural History Museum, London, UK) for correction of the text of manuscript; to Dr. V. Mironov (Zoological Institute, St. Petersburg, Russia) for consultations on taxonomy of Eupitheciini; and to Dr. V. Dubatolov (Institute of Systematic and Ecology of Animals, Novosibirsk, Russia) for interpretation of some collection labels.

\section{References}

Alpheraky, S. 1897: Lepidopteren aus Kamtschatka, gesammelt von O. Herz, bearbeitet von S. Alpheraky. - In: Romanoff, N. M. (ed.), Memoires sur les Lepidopteres, Vol. 9: 301-347. St.Petersburg.

Beljaev, Е. А. (Беляев, Е. А.) 1988: (Family Geometridae). — In: Beljaev, E. A., Ermolaev, V. P., Kirpichnikova, V. A., Kononenko, V. S. \& Tschistjakov, Yu. A. (Беляев, Е. А., Ермолаев, В. П., Кирпичникова, В. А., Кононенко, В. С. \& Чистяков, Ю. А.) (eds.)?? The Lepidoptera - pests of the agriculture and forestry in the Far East. Keys): 130-149. Far Eastern Branch of the Academy of Sciences of the USSR, Vladivostok. [In Russian].

Beljaev, Е. А. (Беляев, Е. А.) 1995: (Family Geometridae). - In: Storozhenko, S. Yu. \& Kuznetsov, V. N. (Стороженко, С. Ю. \& Кузнецов, В. Н.) (eds.), (The Insects - pests of the agriculture in the Far East): 147152. Dal'nauka, Vladivostok. [In Russian].

Beljaev, E. A. \& Kuranishi, R. B. 2000: Geometrid moths (Lepidoptera: Geometridae) collected from the Kamchatka Peninsula and the North Kuril Islands in 19961997. — Nat. Hist. Res., Special Issue 7: 235-242.

Bryk, F. 1942: Zur Kenntnis der Großschmetterlinge der Kurilen. - Deutsche Entomologische Zeitschrift, Iris 55: 3-90.

Bryk, F. 1949: Zur Kenntnis der Großschmetterlinge von Korea. Pars II. - Arkiv för Zoologi 41A: 1-217.

Choi, S.-W. 1998a: Systematic of the genus Cidaria Treitschke (Lepidoptera, Geometridae, Larentiinae). Zoological Journal of the Linnean Society 122: 555580 .

Choi, S.-W. 1998b: Systematics of the genus Heterothera Inoue (Lepidoptera, Geometridae: Larentiinae). Tijdschrift voof Entomologie 141: 19-47.

Covell, Ch. V. 1983: Sterrhinae. - In: Hodges, R. W. et al. 
(eds.), Check List of the Lepidoptera of America north of Mexico: 99-101. E. W. Classey Limited, London.

Djakonov, A. M. 1926: Zur Kenntnis der Geometriden fauna des Minussinsk Bezirks (Sibirien, Jenissej Gouv.). Jahrbuch des Martjanov'schen Staatsmuseums in Minussinsk (Sibirien) 4(1): 1-78. [In Russian and German].

Djakonov, A. 1929: Entomologische Ergebnisse der schwedischen Kamtchatka-Expedition 1920-1922. 20. Lepidoptera III. Geometridae. - Arkiv för Zoologi 21A (1): $1-23$, pl. 1-2.

Djakonov, А. М. (Дьяконов, А. М.) 1931: (Fauna of the geometrid moths (Lepidoptera, Geometridae) of Kamchatka.) - Annuarie du Musée Zoologique de l'Académie des Sciences de l'URSS 32: 385-410. [In Russian and German].

Efremova, L. S. \& Vakulenko, V. V. (Ефремова, Л. С. \& Вакуленко, В. В.) 1971: (Forestry pathological condition of the forests in the Kamchatsk Province and ways of its improvement.) - In: Vasilyev, N. G. (Васильев, Н. Г.) (ed.), (Biological resources of the land of the north of the Far East) 2: 253-257. Far Eastern Branch of the Academy of Sciences of the USSR, Vladivostok. [In Russian].

Ferguson, D. C. 1983: Geometridae (except Sterrhinae). In: Hodges, R. W. et al. (eds.), Check List of the Lepidoptera of America north of Mexico: 88-99, 101-107. E. W. Classey Limited, London.

Imby, A. L. \& Hellberg, H. 1974: Anteckningar om några nordliga Cidariinae (Lepidoptera, Geometridae). Entomol. Tidskr. 95: 192-198.

Inoue, H. 1955: Descriptions and records of some Japanese Geometridae. - Tinea 2: 73-88.

Inoue, H. 1977: Catalogue of the Geometridae of Japan (Lepidoptera). - Bull. Fac. Domestic Sci., Otsuma Woman's Univ. 13: 227-346.

Inoue, H. 1982: Geometridae. — In: Inoue, H., Sugi, S., Kuroko, H., Motiuti, S. \& Kawabe, A. (eds.), Moths of Japan 1: 425-573; 2: 263-310, pls. 55-108, 228-229, 232, 277, 314-344. Kodansha, Tokyo.

International Code of Zoological Nomenclature 2000: 4th ed. The International Trust for Zoological Nomenclature, London: i-xxix, 1-306.

Ivliev, L. А. (Ивлиев, Л. А.) 1963: (The pests of the forests in the Kamchatka and measures of its combating.) - In: Tropin, I. V. (Тропин, И. Вю.) (ed.), (Protection of the green plantings from the pests and diseases): 68-74. Central Scientific-Research Institute of the Technical-Economic Investigations, Moscow. [In Russian].

Ivliev, L. А. (Ивлиев, Л. А.) 1966: (The main forests pests in the Kamchatka and possible measures of their control.) - In: Portenko, L. А. (Портенко, Л. А.) (ed.), Entomofauna of the forests of the Kuril Islands, the Kamchatka Peninsula and Magadansk Province: 7789. Nauka, Moscow-Leningrad. [In Russian].

Ivliev, L. A. \& Kononov, D. G. (Ивлиев, Л. А. \& Кононов, Д. Г.) 1962: (About some mass pests of the seeds of coniferous trees in the Kamchatka.) - Reports of the
Far Eastern Division of the Siberian Branch of the Academy of Sciences of the USSR 15: 83-94. [In Russian].

Konovalova, Z. А. (Коновалова, 3. А.) 1970: (Fauna of the geometrid moths (Lepidoptera, Geometridae) of the Kuril Islands.) - In: Ivliev, L. A. \& Konovalova, Z. А. (Ивлиев, Л. А. \& Коновалова, 3. А.) (eds.), (Entomological researches in the Far East 1) (Transactions of the Institute of the Biology and Soil Science 2): 169173. Far Eastern Division of the Siberian Branch of the Academy of Sciences of the USSR, Vladivostok. [In Russian].

Kryvolutskaja [=Krivolutzkaja, Krivolutskaja], G. O. (Криволуцкэя, Г. О.) 1973: Entomofauna of the Kuril Islands. Principal features and origin. — Nauka, Leningrad. 315 pp. [In Russian].

Kurentzov, А. I. (Куренцов, А. И.) 1963: (Zoogeography of Kamchatka). — In: Soboleva, P. G. \& Ivliev, L. A. (Соболева, П. Г. \& Ивлиев, Л. А. (ed.), Fauna of the Kamchatsk Province: 4-60. Academy of Sciences of the USSR, Moscow-Leningrad. [In Russian].

Kurentzov, А. І. (Куренцов, А. И.) 1966: (On the zoogeographic features of the Kamchatian fauna.) - In: Portenko, L. А. (Портенко, Л. А.) (ed.), Entomofauna of the forests of the Kuril Islands, the Kamchatka Peninsula and Magadansk Province: 63-76. Nauka, Moscow-Leningrad. [In Russian].

Kurentzov, A. I. \& Ivliev, L. А. (Куренцов, А. И. \& Ивлиев, Л. А.) 1960: (About the pests of the Pinus pumila in the Kamchatka.) - Proceedings of the Siberian Branch of the Academy of Sciences of the USSR 11: 97-103. [In Russian].

Lafontaine, J. D. \& Wood, D. M. 1997: Butterflies and moths (Lepidoptera) of the Yukon. - In: Danks, J. H. V. \& Downes, J. A. (eds.), Insects of Yukon. Biological Survey of Canada (Terrestrial Arthropods): 723-785. Ottawa.

Lobkova, L. Е. (Лобкова, Л. Е.) 1986: (Material to the ecology of the most common Lepidoptera - phytophagous of the stony birch.) - In: Amirkhanov, A. M. (Амирханов, А. M.) (ed.), (Fauna and ecology of the invertebrate animals in the reserves of the RSFSR): 105114. Central Scientific-Research Laboratory of the Hunting Industry and Reserves, Moscow. [In Russian].

Matsumura, S. 1925: An enumeration of the butterflies and moths from Saghalien, with description of new species and subspecies. - J. Coll. Agric. Hokkaido imp. Univ. 15: 83-196, pls 8-11.

Mironov, V. G. (Миронов, В. Г.) 1990: A systematic catalogue of geometrid moths of the tribe Eupitheciini (Lepidoptera, Geometridae) from fauna of the USSR. I. Entomol. Obozr. 69 (3): 956-670. [In Russian].

Mironov, V. G. (Миронов, В. Г.) 1991: A systematic catalogue of geometrid moths of the tribe Eupitheciini (Lepidoptera, Geometridae) from fauna of the USSR. II. Entomol. Obozr. 70 (1): 157-167. [In Russian with English summury].

Mironov, V. G. (Миронов, В. Г.) 2000: Systematics of the geometrid moths tribe Perizomini (Lepidoptera, Geo- 
metridae, Larentiinae). — Entomol. Obozr. 79 (1): 112122. [In Russian].

Nordström, F. 1927: Lampropteryx (Cidaria) otregiata Metcalfe, minna Btlr. och suffumata $\mathrm{Hb}$. — Entom. Tidskr. 48: 161-166, pl. 9.

Parsons, M. S., Scoble, M. J., Honey, M. R., Pitkin, L. M. \& Pitkin, B. R. 1999: The catalogue. — In: Scoble, M. J. (ed.), Geometrid moths of the world: a catalogue (Lepidoptera, Geometridae): 1-1016. The Natural History Museum, London.

Prout, L. B. 1912-1916: Die spannerartigen Nachtfalter. —In: Seitz, A. (ed.), Die Gross-Schmetterlinge der Erde 4: i-v+1-479, pl. 1-25. Verlag A. Kernen, Stuttgart.

Prout, L. B. 1934-1939: Geometridae [except Ennominae]. - In: Seitz, A. (ed.), Die Gross-Schmetterlinge der Erde, Bd. 4 (Supplement): 1-253. pl. 1-18. Verlag A. Kernen, Stuttgart.

Sato, R. 2001. Type specimens of the Geometridae (Lepidoptera) described by Matsumura in the Hokkaido University Collection, Japan. - Ins. Matsum. n. s. 58: $115-138$.

Sedyh, K. F. (Седых, К. Ф.) 1979: Lepidoptera (Macrolepidoptera) of the fauna of the Kamchatka and adjacent provinces. - Entomol. Obozr. 58 (2): 288-298. [In Russian].

Semakov, V. V. (Семаков, В. В.) 1971: (Entomofauna of the agrocenoses of the Kamchatka and ways of its forming.) - In: Vasilyev, N. G.(Васильев, Н. Г.) (еd.), (Biological resources of the land of the north of the Far East) 2: 214-220. Far Eastern Branch of the Academy of Sciences of the USSR, Vladivostok. [In Russian].

Semakov, V. V. (Семаков, В. В.) 1972: (To the question on the species composition of the harmful entomofauna of the agricultural crops of the Kamchatsk Province In: Garin, N. A., Kabluchko, L. D. \& Volenko, O. P. (Гарин, Н. А., Каблучко, Л. Д. \& Воленко, О. П.) (eds.), The Kamchatian State Agricultural Experemental Station. Scientific transactions 1 (1971): 56-62. Petropavlovsk-Kamchatskii. [In Russian].

Smetanin, А. А. (Сметанин, А. А.) 1989: (An outbreak of the leaf-feeding insects in the flood-land of the salmon rivers in the north-eastern Kamchatka.) - In: Medvedev, G. S. (Медведев, Г. С.) (ed.), The progress of the entomology in the USSR: Forest entomology: 115-117. Zoological institute of Academy of Sciences of the USSR, Leningrad. (Material of the 10th Congress of the Entomological Society 11-15 September 1989) [In Russian].

Staudinger, O. \& Rebel, H. 1901: Catalog der Lepidopteren des Palaearktischen Faunengebietes I. - R. Friedländer \& Sohn, Berlin. $32+411$ pp.

Troubridge, J. T. 1997: Revision of the Nearctic species of the genus Entephria Hübner (Lepidoptera, Geometridae, Larentiinae). — Ent. Scand., 28: 121-139.

Vasilenko, S. V. (Василенко, С. В.) 1990: A review of the species of the Entephria polata Dup. group (Lepidoptera, Geometridae). - In: Zolotarenko, G. S. (Золотаренко, Г. C.) (ed.), Taxonomy of the insects and helminthes: 79 89. Nauka, Novosibirsk. [In Russian].

Vasilenko, S. V. 1992: Moths from Southern Sakhalin and Kunashir collected in 1989. Part. 3. Geometridae excluding Ennominae. - Japan Heterocerists' J., 166: 282-285.

Vasilenko, S. V. (Василенко, С. В.) 1995: A review of the geometrid moths of the Xanthorhoe sajanaria group (Lepidoptera, Geometridae). — Entomol. Obozr. 74 (3): 662-668. [In Russian with English summary].

Viidalepp, J. (Вийдалепп, Я.) 1975: On the fauna of the geometrid moths (Lepidoptera, Geometridae) of the Mongolian People's Republic. — Insects of Mongolia 3: 438-490. [In Russian].

Viidalepp, J. (Вийдалепп, Я.) 1976: A list of Geometridae of the fauna of the USSR, I. - Entomol. Obozr. 55 (4): 842-852. [In Russian with English summary].

Viidalepp, J. (Вийдалепп, Я.) 1977: A list of Geometridae of the fauna of the USSR, II. - Entomol. Obozr. 56 (3): 564-575. [In Russian].

Viidalepp, J. 1978: (Вийдалепп, Я.) A list of Geometridae of the fauna of the USSR, III. - Entomol. Obozr. 57 (4): 752-761. [In Russian].

Viidalepp, J. (Вийдалепп, Я.) 1979a: A list of Geometridae of the fauna of the USSR, IV. - Entomol. Obozr. 58 (4): 782-798. [In Russian with English summary].

Viidalepp, J. (Вийдалепп, Я.) 1979b: On the fauna of the Lepidoptera of the Tuva ASSR, IV. Geometridae. Acta Comment. Univ. Tartuensis 483 (12): 79-133. [In Russian].

Viidalepp, J. 1996: Checklist of the Geometridae (Lepidoptera) of the former USSR. - Apollo Books, Stenstrup. $111 \mathrm{pp}$.

Viidalepp, J. \& Mironov, V. (Вийдалепп, Я. \& Миронов, B.) 1988a: Pugs of the Soviet Far East (Lepidoptera, Geometridae: Eupithecia), I. - Proc. Estonian Acad. Sci. Biology 37: 200-214. [In Russian with English summary].

Viidalepp, J. \& Mironov, V. (Вийдалепп, Я. \& Миронов, B.) 1988b: Pugs of the Soviet Far East (Lepidoptera, Geometridae: Eupithecia), II. — Proc. Estonian Acad. Sci. Biology 37: 281-293. [In Russian with English summary].

Wehrli, E. 1939-1953: Subfamilie Geometrinae. — In: Seitz, A. (ed.), Die Gross-Schmetterlinge der Erde, Vol. 4 (Suppl.): 254-766, pls. 19-53. Verlag A. Kernen, Stuttgart. 